\title{
Inhibitory Interneurons That Express GFP in the PrP-GFP Mouse Spinal Cord Are Morphologically Heterogeneous, Innervated by Several Classes of Primary Afferent and Include Lamina I Projection Neurons among Their Postsynaptic Targets
}

\author{
Robert P. Ganley, ${ }^{1 \star}$ Noboru Iwagaki, ${ }^{1 *}$ Patricia del Rio, ${ }^{1 \star}$ Najma Baseer, ${ }^{1 *}$ (DAllen C. Dickie, ${ }^{1}$ Kieran A. Boyle, ${ }^{1}$ \\ Erika Polgár, ${ }^{1}$ Masahiko Watanabe, ${ }^{2}$ Victoria E Abraira, ${ }^{3}$ Amanda Zimmerman, ${ }^{3}$ John S. Riddell, ${ }^{1}$ and \\ (1)Andrew J. Todd ${ }^{1}$ \\ ${ }^{1}$ Spinal Cord Group, Institute of Neuroscience and Psychology, University of Glasgow, Glasgow G12 8QQ, United Kingdom, ${ }^{2}$ Department of Anatomy, \\ Hokkaido University School of Medicine, Sapporo 060-8638, Japan, and ${ }^{3}$ Department of Neurobiology, Howard Hughes Medical Institute, Harvard Medical \\ School, Boston, Massachusetts 02115
}

\begin{abstract}
The superficial dorsal horn of the spinal cord contains numerous inhibitory interneurons, which regulate the transmission of information perceived as touch, pain, or itch. Despite the importance of these cells, our understanding of their roles in the neuronal circuitry is limited by the difficulty in identifying functional populations. One group that has been identified and characterized consists of cells in the mouse that express green fluorescent protein (GFP) under control of the prion protein (PrP) promoter. Previous reports suggested that PrP-GFP cells belonged to a single morphological class (central cells), received inputs exclusively from unmyelinated primary afferents, and had axons that remained in lamina II. However, we recently reported that the PrP-GFP cells expressed neuronal nitric oxide synthase (nNOS) and/or galanin, and it has been shown that nNOS-expressing cells are more diverse in their morphology and synaptic connections. We therefore used a combined electrophysiological, pharmacological, and anatomical approach to reexamine the PrP-GFP cells. We provide evidence that they are morphologically diverse (corresponding to "unclassified" cells) and receive synaptic input from a variety of primary afferents, with convergence onto individual cells. We also show that their axons project into adjacent laminae and that they target putative projection neurons in lamina I. This indicates that the neuronal circuitry involving PrP-GFP cells is more complex than previously recognized, and suggests that they are likely to have several distinct roles in regulating the flow of somatosensory information through the dorsal horn.
\end{abstract}

Key words: confocal microscopy; galanin; neuronal nitric oxide synthase; whole-cell recording

\section{Introduction}

Lamina II of the dorsal horn contains numerous inhibitory interneurons (Polgár et al., 2003, 2013a), but despite extensive investigation, we still know little about the neural circuits through

Received Jan. 30, 2015; revised March 18, 2015; accepted April 3, 2015.

Author contributions: R.P.G., N.I., P.d.R., A.C.D., J.S.R., and A.J.T. designed research; R.P.G., N.I., P.d.R., N.B., A.C.D., K.A.B., E.P., M.W., V.E.A., A.Z., and A.J.T. performed research; R.P.G., N.I., P.d.R., N.B., A.C.D., K.A.B., E.P., J.S.R., and A.J.T. analyzed data; R.P.G., N.I., P.d.R., A.C.D., M.W., V.E.A., J.S.R., and A.J.T. wrote the paper.

This work was supported by Biotechnology and Biological Sciences Research Council Grants J001082 and $J 000620$ and Medical Research Council Grant L003430. We thank Dr. E.R. Perl, Dr. A.N. van den Pol, and Bonnie Taylor-Blake for the gift of PrP-GFP mice; Dr. T. Yasaka for advice; Dr. D. Ginty for helpful comments on the manuscript; Robert Kerr and Christine Watt for excellent technical assistance; and Dr. P.C. Emson for the nNOS antibody.

The authors declare no competing financial interests.

${ }^{*}$ R.P.G., N.I., P.d.R., and N.B. contributed equally to this work.

Correspondence should be addressed to either Dr. Andrew J. Todd or John S. Riddell, Spinal Cord Group, West Medical Building, University of Glasgow, University Avenue, Glasgow G12 80Q, United Kingdom. E-mail: andrew.todd@ glasgow.ac.uk or john.riddell@ glasgow.ac.uk.

DOI:10.1523/JNEUROSCI.0406-15.2015

Copyright $\odot 2015$ the authors $\quad 0270-6474 / 15 / 357626-17 \$ 15.00 / 0$ which these control transmission of sensory information. This is largely because of the difficulty in defining functional subpopulations (Graham et al., 2007; Todd, 2010; Braz et al., 2014). The most widely accepted classification scheme, developed by Grudt and Perl (2002), identifies four major morphological classes in lamina II: islet, vertical, central, and radial cells. All islet cells are inhibitory, whereas most vertical and radial cells are excitatory, and the central class includes both excitatory and inhibitory cells (Lu and Perl, 2003, 2005; Heinke et al., 2004; Maxwell et al., 2007; Yasaka et al., 2010; Punnakkal et al., 2014). A limitation of this scheme is that many neurons (typically $\sim 25 \%$ ) cannot be assigned to any of these morphological classes. Neurochemistry provides an alternative way of classifying inhibitory interneurons in the superficial laminae. The somatostatin receptor sst ${ }_{2 \mathrm{~A}}$, which is restricted to inhibitory interneurons in this region, is present on $\sim 50 \%$ of these cells (Todd et al., 1998; Polgár et al., 2013a). Subpopulations among the $\mathrm{sst}_{2 \mathrm{~A}}{ }^{+}$neurons express the neuropep- 
tide galanin and neuronal nitric oxide synthase (nNOS), which are found in approximately two-thirds of these cells (Iwagaki et al., 2013; Polgár et al., 2013a). Loss of the galanin- and/or nNOSexpressing inhibitory interneurons from the superficial laminae in mice lacking the transcription factor Bhlhb5 (Kardon et al., 2014 ) is thought to underlie the chronic itch seen in these animals (Ross et al., 2010).

One group of inhibitory interneurons that has been studied in detail consists of cells that express green fluorescent protein (GFP) under control of the prion promoter ( $\mathrm{PrP}$ ) (Hantman et al., 2004; Zheng et al., 2010). These are reported to constitute a homogeneous population in terms of their morphology (central cells) and primary afferent inputs (from TRPV1- and TRPM8expressing unmyelinated fibers), and to have axons that remain in lamina II. We have recently shown that the PrP-GFP cells (which account for $\sim 16 \%$ of the inhibitory interneurons in lamina II) are among those that possess the $\mathrm{sst}_{2 \mathrm{~A}}$ receptor, and that virtually all of them contain nNOS and/or galanin, with $70 \%$ expressing nNOS (Iwagaki et al., 2013). However, studies in the rat have shown that nNOS-expressing interneurons in superficial dorsal horn are morphologically heterogeneous (Valtschanoff et al., 1992) and seldom upregulate the transcription factor Fos in response to intraplantar injection of the TRPV1 agonist capsaicin (Polgár et al., 2013b). In addition, nNOS ${ }^{+}$dendrites receive synapses in type II glomeruli (Bernardi et al., 1995), which originate from myelinated low-threshold afferents (Ribeiro-da-Silva and Coimbra, 1982), whereas $\mathrm{nNOS}^{+}$axons innervate a population of lamina I projection neurons (Puskár et al., 2001).

These discrepancies suggest that the PrP-GFP cells may be more diverse in their morphology and synaptic connections than previously suggested. In this study, we have combined electrophysiological, pharmacological, and anatomical approaches to resolve these issues.

\section{Materials and Methods}

Experiments were approved by the Ethical Review Process Applications Panel of the University of Glasgow and were performed in accordance with the UK Animals (Scientific Procedures) Act 1986.

Slice preparation and electrophysiology. Spinal cord slices were obtained from 88 PrP-GFP mice 4-6 weeks old and of either sex (van den Pol et al., 2002), as described previously (Iwagaki et al., 2013; Dickie and Torsney, 2014). Briefly, the mid-thoracic to sacral spinal cord was isolated during anesthesia with isoflurane (1\%-3\%). The mouse was decapitated, and the spinal cord was transferred to ice-cold dissecting solution containing the following (in mM): $3.0 \mathrm{KCl}, 1.2 \mathrm{NaH}_{2} \mathrm{PO}_{4}, 2.4 \mathrm{CaCl}_{2}, 1.3 \mathrm{MgCl}_{2}, 26.0$ $\mathrm{NaHCO}_{3}, 15$ glucose, 251.6 sucrose, oxygenated with $95 \% \mathrm{O}_{2}$ and $5 \%$ $\mathrm{CO}_{2}$. The dura and pia mater were removed, and parasagittal spinal cord slices $(300 \mu \mathrm{m})$ were cut with a vibrating blade microtome (Microm HM $650 \mathrm{~V}$, Fisher Scientific). In some cases, mice were anesthetized with isoflurane and decapitated, and the spinal cord with attached dorsal roots was removed and placed in ice-cold dissection solution. Following removal of the ventral roots, dorsal root ganglia, dura, and pia mater, the lumbar (L4-L5) spinal cord was embedded in 3\% low-melting-point agar and parasagittal $(400 \mu \mathrm{m})$ or transverse $(500 \mu \mathrm{m})$ spinal cord slices with attached dorsal roots were cut. Slices were kept at room temperature for at least $30 \mathrm{~min}$ in recording solution containing the following (in $\mathrm{mm}$ ): $125.8 \mathrm{NaCl}, 3.0 \mathrm{KCl}, 1.2 \mathrm{NaH}_{2} \mathrm{PO}_{4}, 2.4 \mathrm{CaCl}_{2}, 1.3 \mathrm{MgCl}_{2}, 26.0$ $\mathrm{NaHCO}_{3}, 15$ glucose, oxygenated with $95 \% \mathrm{O}_{2}, 5 \% \mathrm{CO}_{2}$.

Targeted whole-cell patch-clamp recordings were made from GFPpositive neurons visualized under fluorescence and infrared differential interference contrast microscopy on an Olympus BX51WI microscope. Patch pipettes were pulled with a horizontal puller (P-97, Sutter Instruments) from thin-walled glass capillaries (World Precision Instruments). The pipettes were filled with internal solution containing the following (mM): 130 potassium gluconate, $10 \mathrm{KCl}, 2 \mathrm{MgCl}_{2}, 10 \mathrm{HEPES}, 0.5$ EGTA,
2 ATP-Na $2,0.5$ GTP-Na, pH adjusted to 7.3 with $1 \mathrm{M} \mathrm{KOH}$, and typically had a resistance of 4-6 $\mathrm{M} \Omega$. In some cases, an internal solution containing the following was used (in mM): 120 Cs-methylsulfonate, $10 \mathrm{Na}$ methylsulfonate, 10 EGTA, $1 \mathrm{CaCl}_{2}, 10$ HEPES, 5 QX-314-Cl [2(triethylamino)- $N$-(2,6-dimethylphenyl) acetamine chloride], and 2 $\mathrm{Mg}^{2+}$-ATP, pH adjusted to 7.2 with $\mathrm{CsOH}$, osmolarity $290 \mathrm{mOsm}$. Neurobiotin $(0.2 \%$, Vector Laboratories) was also included in the internal solution for subsequent morphological analysis of recorded cells. Patchclamp signals were amplified and filtered ( $4 \mathrm{kHz}$ low-pass Bessel filter) with a MultiClamp 700B amplifier (Molecular Devices) and acquired at $10 \mathrm{kHz}$ using a Digidata $1440 \mathrm{~A}$ A/D board and pClamp 10 software (Molecular Devices).

Following successful configuration of whole-cell mode, cells were voltage-clamped at $-60 \mathrm{mV}$. Small voltage pulses were delivered (100 $\mathrm{ms},-70$ to $-50 \mathrm{mV}, 2.5 \mathrm{mV}$ increments) to generate current-voltage $(I-V)$ relationships for the recorded cells. These were used to determine resting membrane potentials, and cells exhibiting potentials more depolarized than $-30 \mathrm{mV}$ were not analyzed further. In current-clamp mode, cells were examined for their patterns of action potential firing. Cells were sometimes injected with continuous bias currents to give membrane potentials $\sim-60 \mathrm{mV}$, and then depolarizing current steps $(1 \mathrm{~s})$ were applied until firing reached maximal steady state.

To investigate primary afferent input to GFP-positive neurons, evoked EPSCs (eEPSCs) were recorded in spinal cord slices with attached dorsal roots in response to dorsal root stimulation, as described previously (Torsney and MacDermott, 2006; Daniele and MacDermott, 2009; Torsney, 2011). Cells were voltage-clamped at $-70 \mathrm{mV}$, and the dorsal root was stimulated with a suction electrode. To determine the fiber types providing input to the recorded neurons, stimuli were initially applied at low frequency $(0.05 \mathrm{~Hz}$, stimulus duration $0.1 \mathrm{~ms})$ using an ISO-Flex stimulus isolator (AMPI Intracell), with progressively increasing intensities. The stimulation intensities used were $25 \mu \mathrm{A}$ for $\mathrm{A} \beta$ fibers, $100 \mu \mathrm{A}$ for $\mathrm{A} \delta$ fibers, and $500 \mu \mathrm{A}$ and $1 \mathrm{~mA}$ for $\mathrm{C}$ fibers. Three stimuli were applied at each intensity. Cells in which no monosynaptic response was evident at $1 \mathrm{~mA}$ were additionally stimulated at 3 and $5 \mathrm{~mA}$. Primary afferent input was characterized as monosynaptic or polysynaptic in the manner of Nakatsuka et al. (2000), as described previously (Torsney and MacDermott, 2006; Torsney, 2011). Dorsal roots were stimulated 20 times at $20 \mathrm{~Hz}$ for $\mathrm{A} \beta$ fibers, $2 \mathrm{~Hz}$ for $\mathrm{A} \delta$ fibers, and $1 \mathrm{~Hz}$ for $\mathrm{C}$ fibers. $\mathrm{A}$ fiber responses were considered monosynaptic if there was an absence of failures and a latency variability of $<2 \mathrm{~ms}$, whereas $C$ fiber responses were classified as monosynaptic if there was an absence of failures, regardless of whether the latency was variable. The estimated conduction velocity for monosynaptic primary afferent inputs was calculated on the basis of the response latency, measured as the time between the stimulus artifact and the onset of the monosynaptic eEPSC and the length of the stimulated dorsal root, measured as the distance between the stimulation electrode and the dorsal root entry zone.

To provide information about monosynaptic inputs from primary afferents that possess transient receptor potential (TRP) channels, miniature EPSCs (mEPSCs) were recorded in the presence of TTX $(0.5 \mu \mathrm{M})$, bicuculline $(10 \mu \mathrm{M})$, and strychnine $(5 \mu \mathrm{M})$ while the cell was held at -60 $\mathrm{mV}$. Following a $5 \mathrm{~min}$ control period, drugs (capsaicin $2 \mu \mathrm{M}$, icilin 20 $\mu \mathrm{M}, \mathrm{A} 9670795 \mu \mathrm{M}$ ) were bath-applied via 3-way stopcocks without any change in perfusion rate $(2 \mathrm{ml} / \mathrm{min})$. For experiments with icilin, bath temperature was raised to $\sim 32^{\circ} \mathrm{C}$ with an in-line heating perfusion tube (HPT-2, ALA Scientific Instruments) and a control system (PCT-10, ALA Scientific Instruments). mEPSCs were detected off-line by using Mini Analysis Program software (Synaptosoft). TTX, icilin, and A967079 (selective TRPA1 channel blocker) were obtained from Tocris Bioscience, and 1(S),9(R)-(-)-bicuculline methiodide, strychnine hydrochloride, and capsaicin from Sigma-Aldrich. Following recording, slices were immersion fixed overnight in $4 \%$ formaldehyde at $4^{\circ} \mathrm{C}$.

Morphological analysis of neurons that had undergone whole-cell recording. Following fixation, slices containing recorded cells were rinsed in PBS and incubated overnight at $4^{\circ} \mathrm{C}$ in avidin-Rhodamine (1:1000; Jackson ImmunoResearch Laboratories) diluted in PBS containing 0.3\% Triton X-100. They were then mounted on slides and scanned with a Zeiss LSM 710 confocal microscope equipped with argon multiline, $405 \mathrm{~nm}$ 
diode, $561 \mathrm{~nm}$ solid state and $633 \mathrm{~nm}$ HeNe lasers, and a spectral detection system. Confocal image stacks of filled cells were acquired by scanning through a $63 \times$ oil-immersion lens (NA 1.4) with $0.5 \mu \mathrm{m} z$ spacing and the aperture set to 1 Airy unit. Scans were obtained to include all of the dendritic tree and axonal arbor that was visible at this stage, and these were analyzed offline. In all cases, the presence of GFP was confirmed by scanning for the native protein within the cell bodies of the filled neurons. Axons could readily be distinguished from dendrites because they were generally thinner, showed little tapering at increasing distance from the soma, lacked spines, and possessed numerous irregularly spaced varicosities (Grudt and Perl, 2002; Yasaka et al., 2010).

Initially, the dendritic trees and axonal arbors of the cells were manually reconstructed by using the Neuron Tracing feature in Neurolucida for Confocal software (MBF Bioscience). Slices were then mounted in agar and resectioned at $60 \mu \mathrm{m}$ with a vibrating blade microtome (Leica VT 1200), and the sections were kept in serial order. Sections that contained parts of the dendritic or axonal tree that were deep within the slice and had not previously been visible were scanned, and these were added to the reconstruction. To determine laminar boundaries, one section from each slice was immunostained to reveal PKC $\gamma$ (see below), which is present in a plexus of dendrites that occupies the inner half of lamina II (IIi) (Hughes et al., 2003). Expression of the neurokinin 1 receptor (NK1r) has been used to identify lamina I (Polgár et al., 2011). However, we found that the quality of NK1r immunostaining was generally poor in the resectioned slices, and we therefore defined lamina I as the region up to $20 \mu \mathrm{m}$ below the dorsal white matter, based on observations in perfusion-fixed tissue. These laminar boundaries were added to each of the cell reconstructions. In total, 87 PrP-GFP cells were reconstructed for morphological analysis. Morphometric data for cell bodies, dendritic trees, and axonal arbors of the reconstructed cells were obtained from Neurolucida Explorer.

Because the great majority of PrP-GFP cells express nNOS and/or galanin (Iwagaki et al., 2013), we tested for the presence of these in 72 of the reconstructed cells (those for which there was at least one additional section available for immunocytochemistry). This was done by incubating a section from each cell that contained axonal boutons and/or part of the dendritic tree with a mixture of antibodies against nNOS and galanin. These were then revealed with secondary antibodies conjugated to Alexa-647 and Pacific blue, respectively, as described below. The cell was classed as nNOS-

or galanin-positive if the corresponding type of immunoreactivity was detected in either the axon (at least 5 boutons) or dendrites.

Perfusion fixation. Fifteen PrP-GFP mice of either sex (20-37 g; University of Glasgow, Biological Services) were deeply anesthetized with pentobarbitone (30 mg i.p.) and perfused through the left ventricle with fixative that contained $4 \%$ freshly depolymerized formaldehyde ( 13 mice, tissue for confocal microscopy) or $4 \%$ formaldehyde $/ 0.2 \%$ glutaraldehyde (2 mice, tissue for combined confocal/electron microscopy). Midlumbar spinal cord segments (L3-L5) were dissected out and postfixed for between 4 and $24 \mathrm{~h}$ in the same fixative. These were cut with a vibrating blade microtome into 60 - $\mu \mathrm{m}$-thick transverse, horizontal or sagittal sections and processed for immunocytochemistry. In addition, 2 RetCreER ${ }^{+}$;Ai34 ${ }^{+}$mice (Luo et al., 2009) born to females that had been treated with $2.5 \mathrm{mg}$ tamoxifen at E10.5 and E11.5, were fixed by perfusion, as described above, and parasagittal sections were cut through midlumbar segments.

General features of immunocytochemistry. Immunocytochemistry was performed on sections cut from the slices used for electrophysiology and of $<150 \mathrm{pA}$ current.
Table 1. Antibodies used in this study

\begin{tabular}{lllll}
\hline Antibody & Species & Dilution & Source & Catalog \# \\
\hline GFP & Chicken & $1: 1000-1: 5000$ & Abcam & ab13970 \\
VGAT & Rabbit & $1: 1000$ & Synaptic Systems & 131002 \\
VGAT & Goat & $1: 1000$ & M Watanabe & \\
VGAT & Mouse & $1: 1000$ & Synaptic Systems & 131011 \\
VGLUT1 & Guinea pig & $1: 500-1: 5000$ & Millipore & ab5905 \\
VGLUT2 & Guinea pig & $1: 1000$ & Millipore & ab2251 \\
NK1r & Rabbit & $1: 10000$ & Sigma-Aldrich & S8305 \\
nNOS & Rabbit & $1: 2000$ & Millipore & $07-571$ \\
nNOS & Sheep & $1: 2000$ & PC Emson & \\
Gephyrin & Mouse & $1: 500-1000$ & Synaptic Systems & 147011 \\
Galanin & Rabbit & $1: 1000$ & Bachem & T-4334 \\
BSlectin I & Goat & $1: 2000$ & Vector & AS-2104 \\
CGRP & Guinea pig & $1: 10000$ & Bachem & T-5027 \\
Fos & Goat & $1: 500$ & Santa Cruz Biotechnology & Sc-52-G \\
PKC $\gamma$ & Guinea pig & $1: 500$ & M Watanabe & \\
\hline
\end{tabular}

Figure 1. Electrophysiological properties of PrP-GFP neurons. a, Most of these exhibited tonic firing ( 99 of 138 cells, $72 \%$ ) in $(13 \%)$, single-spiking (7\%), or unresponsive (9\%) patterns. $\boldsymbol{b}$, The relationship between firing frequency and injected current , with data pooled from tonic and initial bursting cells. Because individual cells fired across a slightly different range of injected 作 SEM. The $f-$ / relationship demonstrates that most cells (101 of 117 cells, $86 \%$ ) reached their maximal steady state with injections

also on perfusion fixed tissue. Incubations in primary antibodies were for $3 \mathrm{~d}$, whereas those in secondary antibodies were overnight, at $4^{\circ} \mathrm{C}$ in each case. Antibodies were diluted in PBS that contained 0.3\% Triton X-100 and $5 \%$ normal donkey serum, unless otherwise stated. Details of the sources and concentrations of primary antibodies are given in Table 1. All secondary antibodies were raised in donkey and were species-specific. Secondary antibodies were conjugated to Alexa-488, Alexa-647, Rhodamine Red, Pacific Blue, or biotin (Jackson ImmunoResearch Laboratories), or to Alexa-568 (Invitrogen), and were used at 1:500, apart from those conjugated to Pacific Blue (1:200) or Rhodamine Red (1:100). Biotinylated secondary antibodies were revealed with avidin-Pacific Blue (1:1000; Invitrogen). Following immunoreaction, sections were mounted in anti-fade medium and stored at $-20^{\circ} \mathrm{C}$. For reactions involving 3 or 4 primary antibodies, these were detected with combinations of Pacific Blue, Alexa-488, Rhodamine Red, and/or Alexa-647, which have widely varying emission spectra. Some reactions involved five different antibodies, and in these cases an additional dye (Alexa-568) was used. Although its emission spectrum overlaps with that of Rhodamine 
a

low frequency $(0.05 \mathrm{~Hz})$
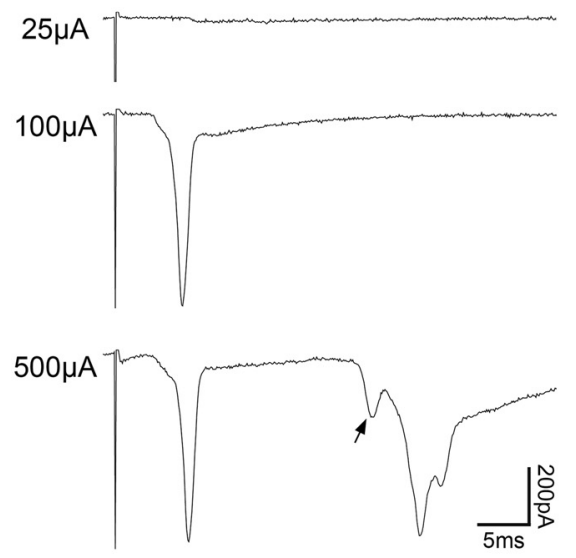

b
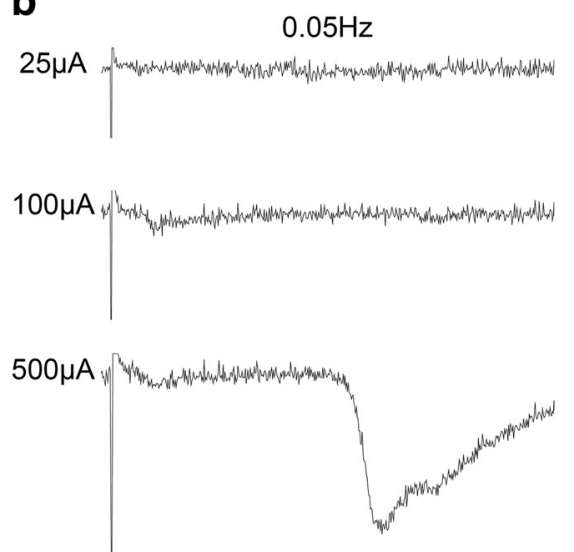

high frequency

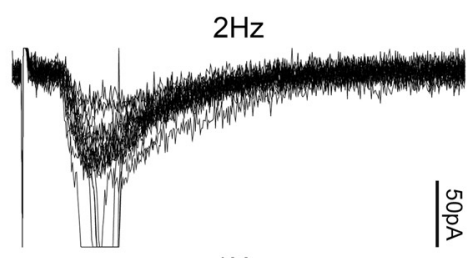

$1 \mathrm{~Hz}$

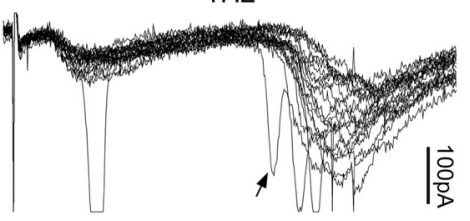

$20 \mathrm{~Hz}$
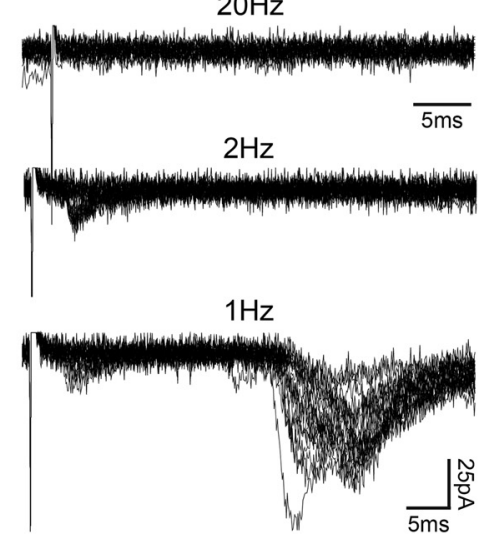

Figure 2. Primary afferent input to PrP-GFP cells. $\boldsymbol{a}, \boldsymbol{b}$, Characterization of primary afferent input to PrP-GFP cells receiving monosynaptic $A \delta$ with monosynaptic ( fiber input, and monosynaptic ( fiber input only, respectively. Left panels, Examples of eEPSCs resulting from low-frequency $(0.05 \mathrm{~Hz})$ dorsal root stimulation at $\mathrm{A} \beta(25 \mu \mathrm{A}), \mathrm{A} \delta(100 \mu \mathrm{A})$, and $\mathrm{C}$ fiber $(500 \mu \mathrm{A})$ intensities; each trace is an average of three recordings. Right panels, Examples of eEPSCs resulting from high-frequency dorsal root stimulation ( $25 \mu \mathrm{A} / 20 \mathrm{~Hz} ; 100 \mu \mathrm{A} / 2 \mathrm{~Hz} ; 500 \mu \mathrm{A} / 1 \mathrm{~Hz})$; each displays 20 superimposed traces. The cell shown in $\boldsymbol{a}$ receives polysynaptic ( fiber input, in addition to the monosynaptic $A \delta$ and monosynaptic ( fiber input. The polysynaptic ( component is seen as the shorter latency response revealed at $500 \mu \mathrm{A}$ stimulation (arrow), which displays failures during high-frequency stimulation. There are larger amplitude responses superimposed upon the monosynaptic A $\delta$ and monosynaptic C fiber eEPSCS, which display failures during high-frequency stimulation and indicate action potential firing. In addition to monosynaptic C-fiber input, the cell shown in $\boldsymbol{b}$ features a small polysynaptic $A \delta$ fiber response, which is evoked during low-frequency stimulation at 100 $\mu \mathrm{A}$ and fails during high-frequency stimulation.

Red, these could be separated reliably with spectral detection, as shown by the lack of coexistence of the two dyes in the resulting confocal images.

Sections were scanned with the confocal microscope through $40 \times$ (NA 1.3) or $63 \times$ oil-immersion lenses, and in all cases the aperture was set to 1 Airy unit. $z$-stacks were acquired, and in many cases overlapping fields were scanned to include the entire cell or region of interest.

Contacts from primary afferents onto $n N O S$-immunoreactive PrP-GFP cells. To identify contacts from nociceptive afferents, we combined binding of Bandeiraea simplicifolia isolectin B4 (IB4), which predominantly labels nonpeptidergic C nociceptors (Hunt and Mantyh, 2001), with immunocytochemical detection of calcitonin gene-related peptide (CGRP), which is expressed by most (if not all) peptidergic primary afferents (Ju et al., 1987; Usoskin et al., 2015). Sagittal sections from 2 perfusion-fixed $\operatorname{Pr}$-GFP mice were incubated overnight in unconjugated IB4 $(1 \mu \mathrm{g} / \mathrm{ml})$, followed by chicken anti-GFP, guinea pig antiCGRP, rabbit anti-nNOS, and a goat antibody that recognizes IB4. These were revealed with appropriate secondary antibodies. Ten $\mathrm{nNOS}^{+}$/ $\mathrm{GFP}^{+}$cells were selected for analysis (5 from each mouse) before the CGRP and IB4 immunostaining were viewed. Confocal scans were ob- tained through the $63 \times$ lens with a $z$-separation of $0.5 \mu \mathrm{m}$. The soma and dendrites were drawn with Neurolucida for Confocal, and the dendritic surface area was determined (Baseer et al., 2012). Dendritic spines were identified and included in the drawings. Contacts between axonal boutons that were either CGRP-immunoreactive or $\mathrm{IB}^{+}{ }^{+} / \mathrm{CGRP}^{-}$and dendritic shafts or spines of the selected neurons were plotted. In each case, we estimated the density of contacts per 1000 $\mu \mathrm{m}^{2}$ of dendritic shaft as well as the percentage of dendritic spines that received a contact.

Myelinated low-threshold mechanoreceptors express VGLUT1 and are the main source of VGLUT1-immunoreactive boutons in lamina IIi-III (Todd et al., 2003; Alvarez et al., 2004). To assess whether these formed contacts with nNOS-immunoreactive GFP cells, we therefore reacted sagittal sections from $3 \mathrm{PrP}$ GFP mice with chicken anti-GFP, guinea pig anti-VGLUT1, and rabbit anti-nNOS, as described above. Twenty-one nNOS ${ }^{+} / \mathrm{GFP}^{+}$ cells with dendrites that entered the plexus of VGLUT1-immunoreactive axons in lamina II were selected ( 7 from each mouse), before individual contacts on the cells could be identified. The dendritic trees of the cells were drawn with Neurolucida, and for those dendrites that lay within the VGLUT1 plexus, the dendritic spines were plotted on the drawings. The channel corresponding to VGLUT1 was then viewed, and the presence or absence of contacts from VGLUT1-immunoreactive boutons on each of the dendritic spines was noted. In this case, the analysis was restricted to dendrites that lay within the VGLUT1 plexus (lamina IIi/ III) because VGLUT1-immunoreactive axons located dorsal to this are likely to be of nonprimary origin (Todd et al., 2003).

To confirm that the contacts from VGLUT1-immunoreactive boutons were associated with synapses, we used a combined confocal/electron microscopic method (Todd et al., 2002; Baseer et al., 2012). Sagittal sections from 2 PrP-GFP mice that had been perfused with glutaraldehyde-containing fixative were initially incubated for $30 \mathrm{~min}$ in $50 \%$ ethanol to improve antibody penetration, and treated for 30 min with $1 \%$ sodium borohydride to reduce free aldehyde sites. They were then incubated in chicken anti-GFP, guinea pig anti-VGLUT1, and rabbit anti-nNOS, followed by corresponding fluorescent secondary antibodies, which were combined with biotinylated anti-chicken and anti-guinea pig antibodies. The sections were then treated with avidin conjugated to HRP (Extravidin-HRP; Sigma-Aldrich; 1:1000) for $24 \mathrm{~h}$ and mounted in anti-fade medium. To preserve ultrastructure, Triton was not included in any of the solutions used in this protocol. The sections were examined with the confocal microscope, and 4 GFP-labeled cells that were also nNOSimmunoreactive ( 2 cells from each animal) were selected and scanned through the $40 \times$ and $63 \times$ lenses, as described above. Contacts between VGLUT1-immunoreactive boutons and the dendritic spines of the selected neurons were identified. The sections were then removed from the slides, reacted with $\mathrm{DAB}$ in the presence of hydrogen peroxide, osmicated, stained en bloc with uranyl acetate, and flat-embedded in Durcupan resin (Baseer et al., 2012). The sections were mounted on blocks of cured resin and trimmed to include the area of interest. They were then cut with a diamond knife into ultrathin sections (silver interference 


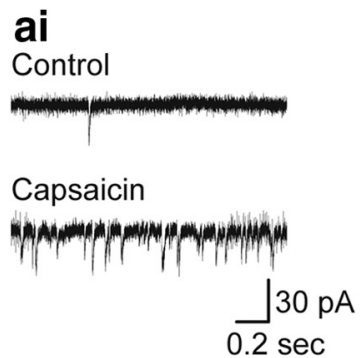

\section{aii}

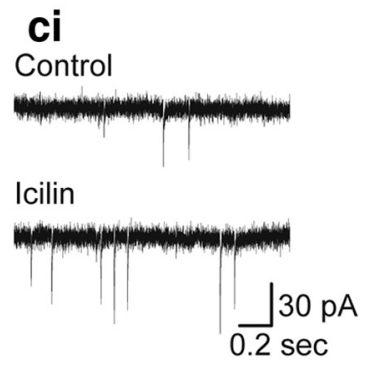

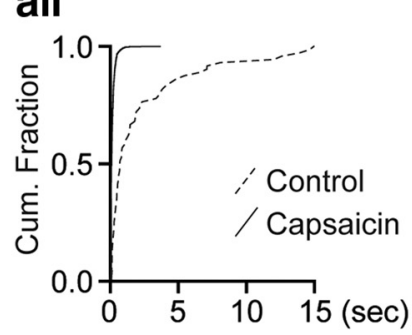

cii

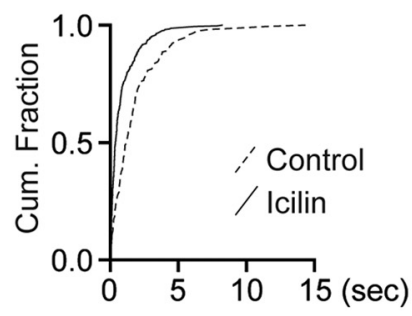

aiii

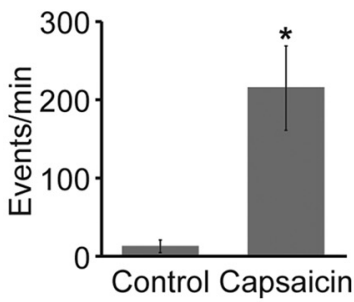

ciii

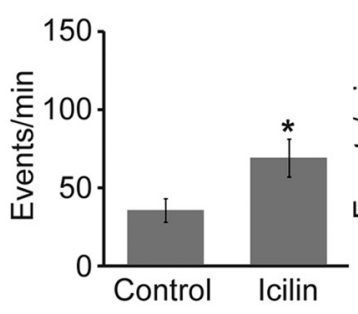

b

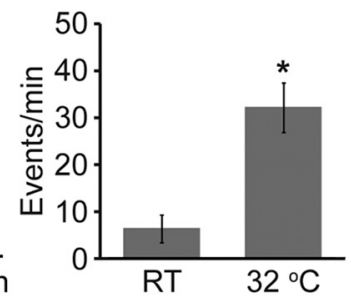

d

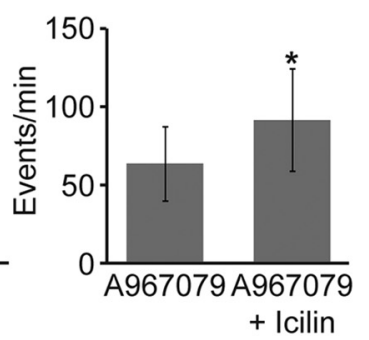

Figure 3. Responses of PrP-GFP neurons to TRP channel agonists and antagonists. $\boldsymbol{a}$, Effects of capsaicin ( $2 \mu \mathrm{m})$ on PrP-GFP cells. ai, Representative raw traces show an increase in mEPSC events upon capsaicin application ( $2 \mu \mathrm{M}$ ). aii, A cumulative probability plot shows a significant decrease in the duration of interevent intervals of mEPSCs (Kolgomorov-Smirnov test, $p<0.05,13$ of 16 cells). aiii, Pooled data show a 16-fold increase in the rate of $\mathrm{mEPSC}$ events/min caused by capsaicin application ( $n=13$, paired $t$ test, $p<0.01$ ). $\boldsymbol{b}$, The rate of baseline $\mathrm{mEPSC}$ events/min increased by fivefold when the temperature in the recording chamber was raised ( $n=36$ at room temperature and $n=24$ at $32^{\circ} \mathrm{C}$, unpaired $t$ test, $\left.p<0.01\right)$. c, Effects of icilin ( $20 \mu \mathrm{M}$ ) on PrP-GFP cells. ci, Representative traces show an increase in mEPSC events caused by icilin application ( $20 \mu \mathrm{m})$. cii, A cumulative probability plot shows a significant decrease in the duration of mEPSC interevent intervals (Kolgomorov-Smirnov test, $p<0.05,14$ of 24 cells). ciii, Pooled data show a twofold increase in mEPSC events/min by icilin application ( $n=14$, paired $t$ test, $p<0.01$ ). $\boldsymbol{d}$, Pooled $\mathrm{mEPSC}$ events/min data showing the response of cells to icilin in the presence of $A 967079$ ( $n=5$, paired $t$ test, $p<0.05$ ). This suggests that at least part of the action of icilin was mediated through TRPM8-expressing afferent terminals that are presynaptic to PrP-GFP cells. All recordings were made in the presence of TTX. Error bars represent SEM.

color, $\sim 70 \mathrm{~nm}$ thickness), which were collected in serial order on Formvar-coated single slot grids and stained with lead citrate. Ultrathin sections were viewed with a Philips CM100 EM, equipped with a digital camera. The contacts between GFP-labeled dendrites and VGLUT1immunoreactive axons (both of which were DAB-labeled) were identified based on their location and their relationship to landmarks (e.g., capillaries and GFP-immunoreactive cell bodies) that could be recognized in both confocal image stacks and ultrathin sections.

To determine whether nNOS-expressing inhibitory interneurons received contacts from $\mathrm{A} \beta$ low-threshold afferents, we used sections from 2 mice derived from a cross between the $\mathrm{RetCreER}{ }^{+}$line and the $\mathrm{Ai34} 4^{+}$ strain (The Jackson Laboratory; stock \#012570) that had been treated prenatally with tamoxifen. Luo et al. (2009) have shown that this strategy labels a set of "early Ret + " afferents, including $\mathrm{A} \beta$ hair afferents and those innervating Meissner's corpuscles, with the resulting tdTomatosynaptophysin fusion protein being targeted to axon terminals. Sections from these mice were reacted with sheep anti-nNOS and guinea pig anti-VGLUT1. Cells with strong labeling for nNOS were selected because this allowed identification of dendritic spines, which are difficult to see in more weakly stained cells. We have reported that, in the rat, $90 \%$ of neurons with strong nNOS immunoreactivity are GABAergic (Sardella et al., 2011a), and we have found that, in the PrP-GFP mouse, $65 \%$ of the lamina II neurons that were strongly nNOS ${ }^{+}$expressed GFP (A.J.T. and F. Garzillo, unpublished data). Six of these cells (3 from each mouse) were scanned with the confocal microscope and analyzed with Neurolucida for Confocal, as described above. In this way, we determined the proportion of dendritic spines belonging to each neuron and located in lamina IIi-III that received contacts from tdTomato-labeled VGLUT1 ${ }^{+}$ boutons.

To test for potential convergence of nociceptive and low-threshold mechanoreceptive input, and to look for evidence that lamina I-projecting cells were innervated by A-LTMRs, we tested for the presence of contacts from VGLUT1-immunoreactive boutons onto dendritic spines of 6 of the recorded neurons. Two of these were cells that had been found to respond to capsaicin, whereas 5 (including one of the capsaicinresponsive cells) had axons that arborized in lamina I. For all of these cells, some dendrites extended into lamina IIi (which includes part of the
VGLUT1 plexus). In each case, a single section that contained part of the dendritic tree was reacted to reveal VGLUT1 and subsequently scanned and analyzed as described above.

Fos expression following intraplantar capsaicin injection. To determine whether nNOS-immunoreactive PrP-GFP cells upregulated the transcription factor Fos following activation of TRPV1 receptors (Polgár et al., 2013b), 3 PrP-GFP mice (either sex, 25-33 g) were briefly anesthetized with isoflurane $(2.5 \%-3 \%)$ and received an injection of $10 \mu 10.05 \%$ capsaicin (dissolved in 7\% Tween 80, 20\% ethanol in saline) into the plantar surface of the left hindpaw. The animals were allowed to recover from anesthesia, and $2 \mathrm{~h}$ later they were reanesthetized with pentobarbitone and perfused with fixative containing $4 \%$ formaldehyde, as described above.

Transverse sections through the L4 segment were reacted with chicken anti-GFP, goat anti-Fos, and rabbit anti-nNOS, and these were revealed with fluorescent secondary antibodies. Four sections were selected from the spinal cord of each mouse, based on the presence of large numbers of $\mathrm{Fos}^{+}$cells, but before the relation of Fos to GFP or nNOS was observed. The sections were scanned with the confocal microscope through the $40 \times$ lens to produce $z$-series ( $1 \mu \mathrm{m}$ spacing) through the full thickness of the section, and these were analyzed with Neurolucida for Confocal. A maximum intensity projection of the Fos staining was initially viewed, and this was used to outline the mediolateral (ML) extent of Fos ${ }^{+}$cells. $\mathrm{GFP}^{+}$neurons within this region that were also nNOS-immunoreactive were then identified and examined for the presence of Fos. Although a stereological method was not used, the sampling bias toward larger cells is likely to have been very small, as the section thickness $(60 \mu \mathrm{m})$ was much larger than the diameters of the neuronal cell bodies (Polgár et al., 2013b).

Analysis of postsynaptic targets. We have identified a population of large lamina I projection neurons (giant cells) in the rat that can be recognized by their very high density of synapses from both excitatory $\left(\mathrm{VGLUT}^{+}\right)$and inhibitory $\left(\mathrm{VGAT}^{+}\right)$boutons and shown that these are selectively innervated by nNOS-containing GABAergic axons (Puskár et al., 2001; Polgár et al., 2008). To test whether similar cells are present in the mouse, and whether they are targeted by axons of PrP-GFP cells, we reacted horizontal sections through the L3-L5 segments of 3 of the 


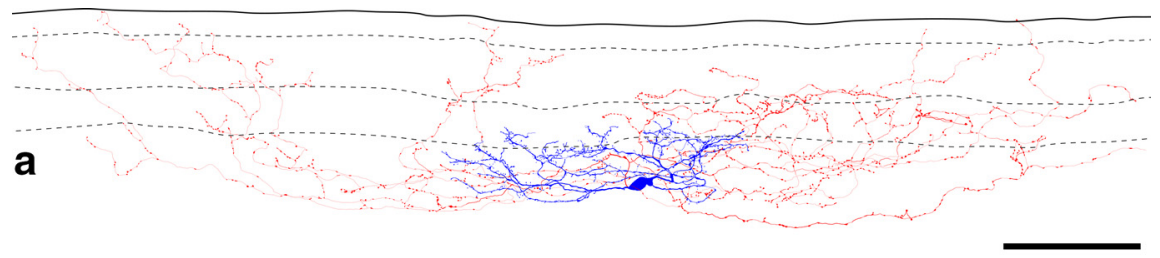

b

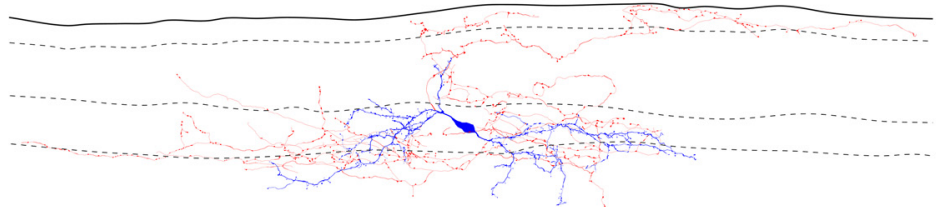

C
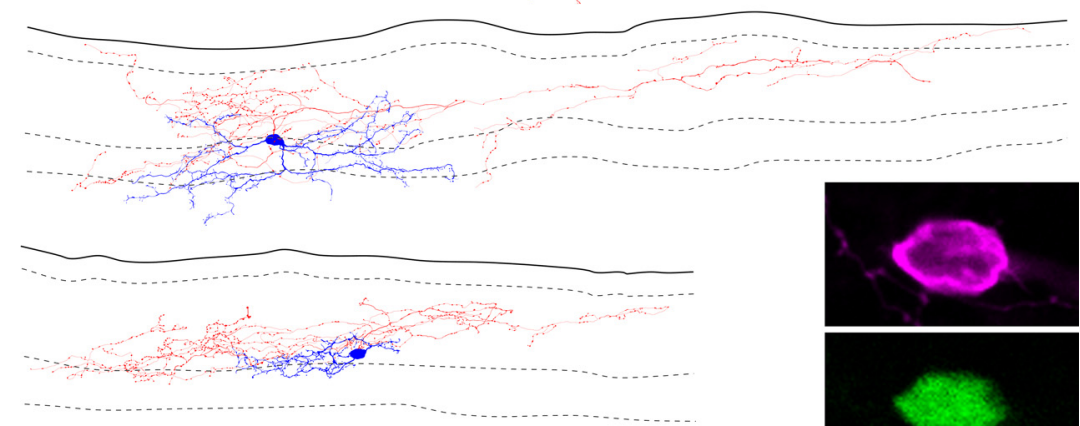

d

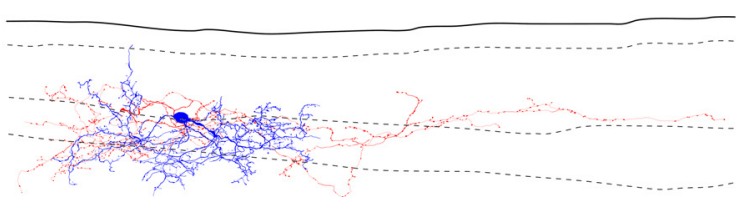

Figure 4. Neuronal morphology. $\boldsymbol{a}-\boldsymbol{e}$, Examples of Neurolucida reconstructions for five of the PrP-GFP neurons, which were recorded in parasagittal slices. In each case, soma and dendrites are shown in blue and axons in red. Top solid line in each drawing indicates the gray-white matter border. Dashed lines indicate the boundaries between laminae I, Ilo Ili, and III. Note the variable dendritic morphology, and also the variation in the distribution of the axonal arborization. For the cells shown in $\boldsymbol{a}-\boldsymbol{c}$, part of the axon enters lamina $I$, where it gives rise to axonal boutons. $\boldsymbol{f}$, Confocal optical section through the soma of the cell illustrated in $\boldsymbol{e}$, showing GFP (green) and Neurobiotin (magenta). D, Dorsal; V, ventral. Scale bars: $\boldsymbol{a}-\boldsymbol{e}, 100 \mu \mathrm{m} ; \boldsymbol{f}, 20 \mu \mathrm{m}$.

Table 2. Laminar distribution of dendrites and axons of recorded neurons ${ }^{a}$

\begin{tabular}{lcc}
\hline Laminae & Dendritic tree & Axonal arbor \\
\hline I-II & $4(5)$ & $10(11)$ \\
I-III & $3(4)$ & $43(49)$ \\
II & $29(36)$ & $3(3)$ \\
II-III & $45(56)$ & $31(36)$ \\
\hline
\end{tabular}

$\overline{{ }^{a} \text { Values are the no. (\%) of cells that had dendrites or axons that extended into different laminae. Dendritic trees were }}$ analyzed for 81 cells, but axonal arbors for 87 cells.

perfusion-fixed mice with a mixture of 5 primary antibodies: guinea pig anti-VGLUT2, rabbit anti-VGAT, mouse anti-gephyrin, chicken antiGFP, and sheep anti-nNOS. The sections were initially viewed with the confocal microscope, and 25 giant cells (7-9 in each mouse) were identified by the high density of VGLUT2 and VGAT boutons that were associated with their cell bodies and dendritic trees (Polgár et al., 2008). To avoid bias, cells were selected before the channel representing GFP was viewed. The cells were scanned through the $63 \times$ lens with the confocal microscope to produce $z$-series $(0.3 \mu \mathrm{m}$ separation). For each cell, several $z$-series were scanned, to include as much of the dendritic tree as was visible within the section. The cells were reconstructed with Neurolucida for Confocal, and the locations of all VGAT boutons that contacted gephyrin-immunoreactive puncta on the cell bodies or dendrites of the selected neurons were plotted. The GFP and nNOS channels were then viewed, and the presence or absence of each of these proteins was noted for each VGAT bouton.

Many lamina I projection neurons in the rat express the NK1r (Todd et al., 2000), and most of the cells in this lamina with strong NK1r immunoreactivity are projection neurons (Al Ghamdi et al., 2009). We there-
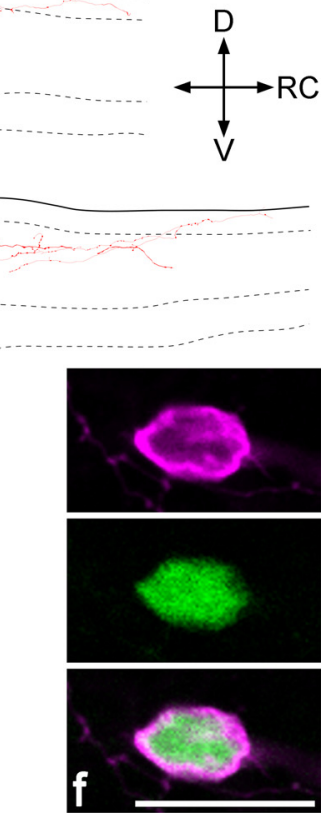

fore tested whether $\mathrm{NK} 1 \mathrm{r}^{+}$cells in lamina I received synapses from axons of PrP-GFP cells, by reacting horizontal sections through the L3 segments of 3 PrP-GFP mice with the following antibody mixture: chicken anti-GFP, rabbit anti-NK1r, goat anti-VGAT, and mouse antigephyrin. The sections were viewed with the confocal microscope, and 60 lamina I neurons with strong NK1r immunoreactivity were selected (20 from each mouse) before the GFP immunostaining was viewed. The cells were scanned as described above, and the resulting $z$-stacks were analyzed with Neurolucida for Confocal. Inhibitory $\left(\mathrm{VGAT}^{+}\right)$boutons that were presynaptic to the dendrites or cell bodies of the NK1r ${ }^{+}$cells were identified by the presence of contacts with an intervening gephyrin punctum, and these were plotted onto drawings of the cells. The GFP channel was then viewed, and the presence or absence of staining in each of the presynaptic $\mathrm{VGAT}^{+}$boutons was recorded.

To assess whether these populations were selectively targeted by PrP-GFP axons, we also assessed the proportion of all inhibitory $\left(\mathrm{VGAT}^{+}\right)$boutons in lamina I that contained GFP. Transverse sections from 4 of the perfusion-fixed mice were reacted with chicken anti-GFP and mouse anti-VGAT. A confocal $z$-series ( $0.3 \mu \mathrm{m} z$-separation $)$ was acquired from each mouse through the $40 \times$ lens and analyzed with Neurolucida for Confocal. A single optical section was chosen from each stack, and 100 VGAT-immunoreactive boutons were selected from the full dorsoventral (DV) extent of lamina I. The GFP channel was then viewed and the proportion of boutons that were $\mathrm{GFP}^{+}$was determined. Because this sampling method would inevitably be biased toward those boutons that were more extensive in the $z$-axis (Guillery, 2002; Polgár et al., 2011), the $z$-axis lengths of VGAT boutons with and without GFP were compared by determining the number of optical sections for which each bouton was visible (Polgár et al., 2011).

Antibody characterization. The chicken anti-GFP antibody was raised against the recombinant full-length protein and the distribution of staining matches that of native GFP. The rabbit and mouse antibodies against VGAT were raised against amino acids $75-87$ of the rat protein, whereas the goat antibody was raised against amino acids $31-112$ of the mouse protein. All three stain a single band of the appropriate molecular weight in blots of brain extracts (Takamori et al., 2000; Miura et al., 2006; Sardella et al., 2011b). The VGLUT1 and VGLUT2 antibodies were raised against sequences of 19 or 18 amino acids (respectively) from the rat proteins, and both stain identical structures to those detected by wellcharacterized rabbit antibodies against the corresponding transporter (Todd et al., 2003). The NK1r antibody was raised against amino acids 393-407 of the rat protein, and staining is absent from mice in which the receptor has been deleted (Ptak et al., 2002). The sheep (Herbison et al., 1996) and rabbit antibodies against nNOS both label a single band of 155 $\mathrm{kDa}$ in rat brain extracts. The monoclonal antibody against gephyrin detects a single $93 \mathrm{kDa}$ band in extracts of rat brain membranes (Becker et al., 1989). Staining with the galanin antibody is absent in the brain of galanin knock-out mice (Makwana et al., 2010). The CGRP antibody detects both $\alpha$ and $\beta$ forms of the peptide (manufacturer's specification). The antibody against $B$. simplicifolia lectin I detects IB4 applied to tissue sections. The Fos antibody was raised against a peptide corresponding to the $\mathrm{N}$ terminus of human Fos, and staining in the superficial dorsal horn was restricted to somatotopically appropriate areas following intraplantar injection of capsaicin. The PKC $\gamma$ antibody, which was raised against 

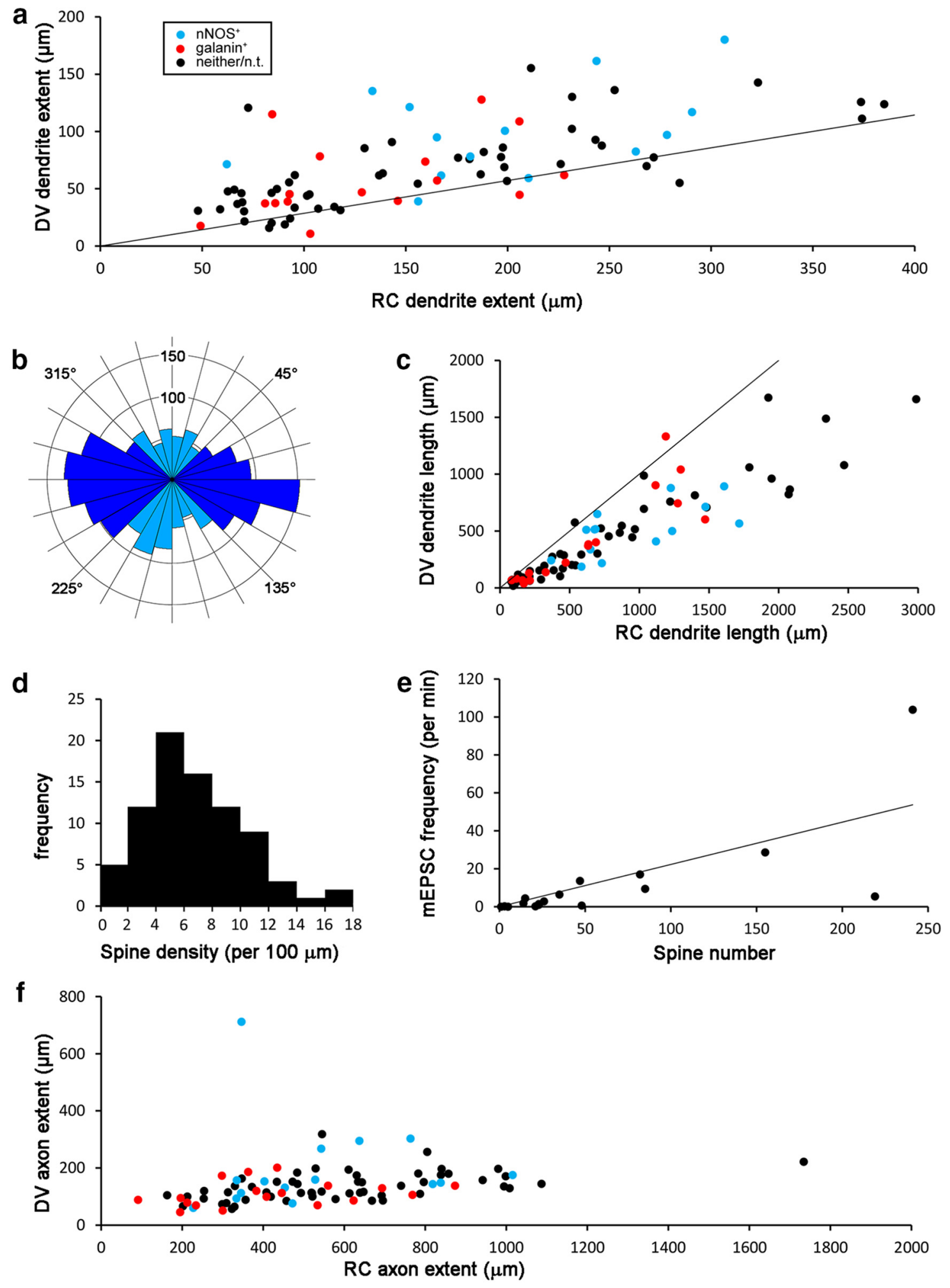

g
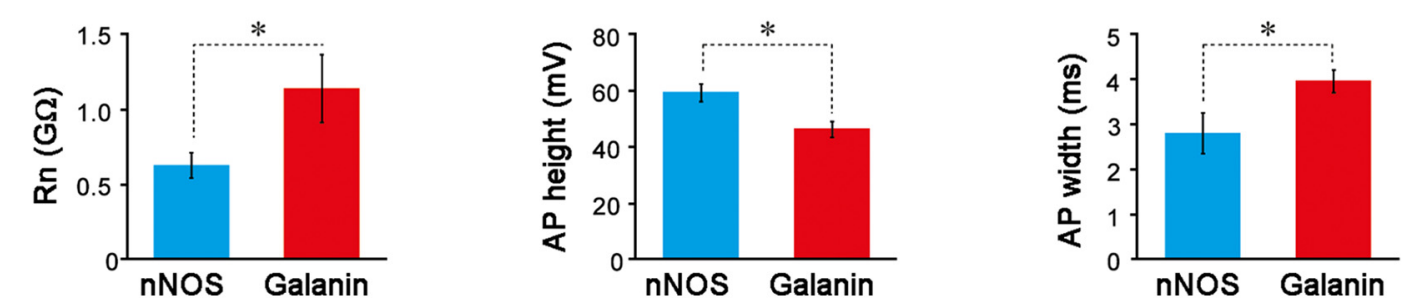
amino acids $648-697$ of the mouse protein, detects a single band at 75 $\mathrm{kDa}$ in wild-type (but not $\mathrm{PKC} \gamma^{-/-}$) mice and stains identical structures to those detected by a well-characterized rabbit antibody (Yoshida et al., 2006; Sardella et al., 2011a).

Statistics. mEPSC interevent intervals in control conditions were compared with those in the presence of drugs by the Kolmogorov-Smirnov test. Spearman rank order correlation was used to compare mEPSC frequency with spine number for reconstructed neurons. Differences in anatomical and electrophysiological properties of the galanin- and nNOS-immunoreactive reconstructed neurons were compared with $t$ tests. The Mann-Whitney $U$ test was used to compare $z$-axis lengths of GFP-positive and -negative VGAT boutons in lamina I. In all cases, a $p$ value $<0.05$ was considered significant.

\section{Results}

\section{Membrane properties of PrP-GFP cells}

To establish the subthreshold $I-V$ relationship, most of the PrPGFP cells that were recorded at room temperature were initially voltage-clamped at $-60 \mathrm{mV}$, and tested with brief voltage pulses ( $100 \mathrm{~ms},-70$ to $-50 \mathrm{mV}, 2.5 \mathrm{mV}$ increments). The resting membrane potential of each cell was calculated based on this individual $I-V$ relationship, and the averaged resting potential was $-53.8 \pm 0.9 \mathrm{mV}$, with an input resistance of $1026.1 \pm 59.9 \mathrm{M} \Omega$ $(n=138)$. Cells were then current-clamped for examination of their patterns of action potential firing. They were presented with continuous bias currents to hold the membrane potential at $\sim-60 \mathrm{mV}$. By gradually incrementing the amount of current injected ( $1 \mathrm{~s}$ steps), it was found that the rheobase was $27.8 \pm 1.6$ $\mathrm{pA}(n=126)$, with a threshold for action potential firing (taken as the point at which rate of rise exceeded $10 \mathrm{mV} / \mathrm{ms}$ ) of $-33.0 \pm$ $0.6 \mathrm{mV}$. The mean action potential height and width were $51.5 \pm$ $1.0 \mathrm{mV}$ and $3.6 \pm 0.1 \mathrm{~ms}$, respectively, whereas the mean afterhyperpolarization amplitude was $26.0 \pm 0.6 \mathrm{mV}$. However, 12 cells did not generate any action potentials in response to the current injection, and these were defined as unresponsive. Suprathreshold current injection was increased until firing reaching its maximal steady state. The majority of recorded cells showed tonic firing $(n=99$, Fig. $1 a)$ or initial bursting $(n=18)$

\section{$\leftarrow$}

Figure 5. Morphometric and electrophysiological data for the recorded neurons. $\boldsymbol{a}$, Scatter plot of RC versus DV extent of the dendritic trees for the 81 neurons with well filled dendrites. The line indicates an RC/DV ratio of 3.5, which was used by Yasaka et al. (2007) to distinguish lamina Il central cells in the rat. Very few of the cells have a ratio greater than this (i.e., fall below the line), and these therefore would not be classified as central cells based on this definition (see text). Blue and red symbols represent cells identified as nNOS or galanin immunoreactive. Black symbols represent cells that were not tested (n.t.) or showed neither type of immunoreactivity. This scheme also applies to parts $\mathrm{c}$ and $\mathrm{f}$. $\boldsymbol{b}$, Polar histogram of the dendritic tree for the cell illustrated in Figure $4 b$ (for further details, see text). The concentric circles represent 50,100 , and $150 \mu \mathrm{m}$. Bins corresponding to orientations between $45^{\circ}-135^{\circ}$ and $225^{\circ}-315^{\circ}$ were grouped (shown in dark blue) and represent predominantly RC orientation. Those for $315^{\circ}-45^{\circ}$ and $135^{\circ}-225^{\circ}$ (light blue) correspond to predominantly DV orientation. c, Scatter plots showing the values for RC and DV dendritic length obtained from the polar histograms of the 81 cells with well-filled dendrites. For nearly all cells $\mathrm{RC}>\mathrm{DV}$, the plots therefore fall below the line (which represents $\mathrm{RC}=\mathrm{DV}$ ). There is considerable variation in total dendritic length, which is the sum of RC and DV. $\boldsymbol{d}$, A frequency histogram for the density of dendritic spines shows considerable variation in their density across the population. $\boldsymbol{e}$, There is a highly significant positive correlation between spine number and mEPSC frequency, for those cells in which the frequency was measured in recordings made at room temperature. $f$, Scatter plot of axonal extent along the DV and RC axis. With the exception of one cell, which had an axon that traveled $\sim 700 \mu \mathrm{m}$ in the ventral direction (arrow), all cells had rostrocaudally elongated axonal arbors, which were considerably longer than their dendritic trees (compare with parta). $\boldsymbol{g}$, Electrophysiological properties that differed significantly between the $\mathrm{nNOS}^{+}$and galanin ${ }^{+}$cells. The $\mathrm{nNOS}^{+}$cells $(n=10)$ had smaller input resistances than the galanin ${ }^{+}$cells $(n=10)$, as well as greater action potential heights and shorter widths ( $n=8 \mathrm{for} \mathrm{the} \mathrm{galanin} \mathrm{cells,} \mathrm{because} 2$ of these were unresponsive). Error bars represent SEM.
(Ruscheweyh and Sandkühler, 2002; Hantman et al., 2004; Graham et al., 2007). Nine cells only generated one or two action potentials in response to an increased amount of current injected, and were therefore defined as single-spiking cells. No delayed or gap firing patterns were observed among the PrP-GFP cells. For those cells that were capable of generating trains of action potentials, the relationship between firing frequency and the amount of injected current ( $f-I$ relationship) was examined (Fig. 1b). The pooled $f-I$ relationship is illustrated up to the injection of $150 \mathrm{pA}$ current because most cells (101 of 117 cells, 86\%) reached their maximal steady state within this range. The maximal firing frequency, averaged across tonic and initial bursting cells, was $28.1 \pm 1.0 \mathrm{~Hz}(n=117)$.

\section{Primary afferent inputs to PrP-GFP cells}

Primary afferent input was examined by dorsal root stimulation in 29 cells, and this resulted in eEPSCs in 17 cells (58.6\%). Among those cells with input, $10(34.5 \%)$ received polysynaptic input only. For one cell, this was from $A \beta$ fibers, whereas for the others it was from C fibers $(n=4), \mathrm{A} \delta$ fibers $(n=1)$, or both $\mathrm{C}$ and $\mathrm{A} \delta$ fibers $(n=4)$. The remaining 7 cells $(24.1 \%)$ received monosynaptic inputs from $\mathrm{C}$ fibers (Fig. 2b), and one of these also received monosynaptic $\mathrm{A} \delta$ and polysynaptic $\mathrm{C}$ input (Fig. 2a). Among the other 6 cells with monosynaptic $C$ fiber input, 1 received polysynaptic $A \beta$ input, 3 polysynaptic $A \delta$ input, and 1 polysynaptic $C$ input. Increasing the stimulation intensity to 3 or $5 \mathrm{~mA}$ did not reveal any additional inputs in those cells that showed no monosynaptic response during dorsal root stimulation at $1 \mathrm{~mA}$. The $\mathrm{C}$ fibers that evoked monosynaptic responses had an estimated conduction velocity of $0.144 \pm 0.003 \mathrm{~m} / \mathrm{s}$, whereas the corresponding value for the A $\delta$ fiber was $0.921 \mathrm{~m} / \mathrm{s}$.

Further evidence for monosynaptic primary afferent inputs to PrP-GFP cells was obtained by analyzing the frequency of mEPSCs following bath application of TRP channel agonists (Yang et al., 1998; Wrigley et al., 2009; Zheng et al., 2010). mEPSCs were recorded while the cells were voltage-clamped at -60 $\mathrm{mV}$ in recording solution that contained TTX $(0.5 \mu \mathrm{M})$, bicuculline $(10 \mu \mathrm{M})$, and strychnine $(5 \mu \mathrm{M})$. After $5 \mathrm{~min}$ of the control condition, the potent TRPV1 agonist capsaicin $(2 \mu \mathrm{M})$ was bath applied and mEPSC frequency was recorded for a further $5 \mathrm{~min}$ (Fig. 3ai). For each recorded cell, cumulative probability plots summarizing mEPSC interevent intervals were produced, and the Kolmogorov-Smirnov test was used to compare the 5 min periods before and after capsaicin administration. This analysis revealed that there was a significant decrease in the duration of mEPSC interevent intervals (i.e., an increase in mEPSC frequency) in 13 of 16 cells (Fig. 3ai,aii). Pooling data from those cells that responded to the capsaicin application, averaged mEPSC frequency (events/min) increased by 16 -fold (13.2 \pm 7.9 to $215.8 \pm 54.3$ events/min; $n=13$; paired $t$ test, $p<0.01$; Fig. 3aiii). This suggests that most PrP-GFP cells receive monosynaptic inputs that originate from TRPV1-expressing primary afferents, consistent with the finding of Zheng et al. (2010). Application of capsaicin did not evoke an inward current in any of these cells.

To determine whether PrP-GFP cells receive inputs from afferents responsible for cold sensation, we applied the widely used cooling agent, icilin (Wrigley et al., 2009). Initial studies performed at room temperature failed to reveal a significant effect, possibly because some TRPM 8 channels would already be open at this temperature. We therefore performed experiments with the bath temperature raised to $\sim 32^{\circ} \mathrm{C}$ and found that this resulted in a fivefold increase in baseline mEPSC frequency $(6.2 \pm 3.0$ to $32.3 \pm 5.3$ events $/ \mathrm{min} ; n=36$ at room temperature and $n=24$ at 
$32^{\circ} \mathrm{C}$; unpaired $t$ test, $p<0.01$; Fig. $\left.3 b\right)$. Application of icilin $(20 \mu \mathrm{M}$; Fig. $3 c i)$ now led to a significant decrease in the duration of interevent mEPSC intervals in 14 of 24 recorded cells (Fig. 3ci,cii). The average frequency of mEPSCs for those that responded to icilin increased by twofold $(35.0 \pm 7.3$ to $68.6 \pm 12.0$ events $/ \mathrm{min} ; n=$ 14 ; paired $t$ test, $p<0.01$; Fig. 3 ciii). Although icilin is known to be a potent TRPM8 agonist, at high concentrations it can also act on TRPA1 channels (Wrigley et al., 2009). Therefore, the possibility of icilin-induced TRPA1 activation was assessed by bath application of a TRPA1 antagonist, A967079 $(5 \mu \mathrm{M})$. In the presence of A967079, application of icilin $(20 \mu \mathrm{M})$ still caused a significant decrease in the duration of mEPSC intervals in 5 of 10 recorded cells, and for these icilinresponsive cells, the frequency of mEPSCs increased by 1.4 -fold $(64.0 \pm 23.8$ to $92.0 \pm 32.9$ events $/ \mathrm{min} ; n=5$; paired $t$ test, $p<0.05$; Fig. $3 d$ ). Again, responses to icilin were not accompanied by an evoked inward current. For 6 of the cells that were recorded with a bath temperature of $32^{\circ} \mathrm{C}$, we initially applied icilin for $\sim 7 \mathrm{~min}$ and then after a recovery period of $10 \mathrm{~min}$ we applied capsaicin. In two of these cases, icilin caused a significant decrease in the duration of mEPSC intervals. Subsequent application of capsaicin caused a decrease in the duration for all six cells. Together, these results suggest that approximately half of the PrP-GFP cells receive monosynaptic input from TRPM8-expressing afferent terminals and that there can be convergence of input from both TRPM8and TRPV1-expressing afferents onto the same cell. They also suggest that some of the cells receive input from TRPV1-expressing primary afferents, but not from those that express TRPM8.

\section{Morphology and neurochemistry of recorded neurons}

In total, 87 of the recorded neurons were reconstructed with Neurolucida, and in all cases the presence of GFP in the soma was confirmed (Fig. 4f). Although the axonal arbors were well labeled in all cases, for 6 of the cells the dendritic tree was very short and appeared to have been truncated. These cells were therefore excluded from the morphometric analysis of dendritic trees. Examples of 5 of the reconstructed neurons are shown in Figure $4 a-e$. Although both the dendritic trees and axonal arbors were generally oriented along the rostrocaudal (RC) axis, the cells had very variable morphology and did not consistently fit into any of the recognized morphological classes (Grudt and Perl, 2002; Heinke et al., 2004; Graham et al., 2007; Maxwell et al., 2007; Yasaka et al., 2007; Wang and Zylka, 2009; Uta et al., 2010; Yasaka et al., 2010; Punnakkal et al., 2014). The cell bodies of 70 of the neurons were located in lamina II, whereas those of the remaining 17 were in lamina III. The laminar location of dendritic trees and axonal arbors of the cells are shown in Table 2. Although all cells had
Table 3. Dendritic and axonal measures for cells that showed nNOS or galanin immunoreactivity $^{a}$

\begin{tabular}{llccl}
\hline & Measure & Galanin & nNOS & $p$ (t test) \\
\hline Soma & Soma depth $(\%)$ & 61 & 83 & $0.023^{*}$ \\
Dendrites & RC extent $(\mu \mathrm{m})$ & 133 & 201 & $0.0053^{* *}$ \\
& DV extent $(\mu \mathrm{m})$ & 59 & 100 & $0.0048^{* *}$ \\
& ML extent $(\mu \mathrm{m})$ & 37 & 58 & $0.01^{* *}$ \\
& Dendrite length $(\mu \mathrm{m})$ & 1208 & 1487 & 0.387 \\
RC length $(\mu \mathrm{m})$ & 629 & 957 & 0.063 \\
DV length $(\mu \mathrm{m})$ & 411 & 510 & 0.43 \\
Axon & RC:DV ratio & 1.97 & 2.03 & 0.86 \\
& Spine density $(\mathrm{per} 100 \mu \mathrm{m})$ & 5.2 & 7.4 & 0.085 \\
& RC extent $(\mu \mathrm{m})$ & 423 & 538 & 0.152 \\
& DV extent $(\mu \mathrm{m})$ & 110 & 199 & $0.0308^{*}$ \\
& ML extent $(\mu \mathrm{m})$ & 37 & 105 & $0.021^{*}$ \\
Axon length $(\mu \mathrm{m})$ & 3584 & 4675 & 0.15 \\
RC length $(\mu \mathrm{m})$ & 2560 & 3265 & 0.21 \\
DV length $(\mu \mathrm{m})$ & 1008 & 1386 & 0.10 \\
RC:DV ratio & 2.6 & 2.6 & 0.97 \\
Bouton density $($ per $100 \mu \mathrm{m})$ & 11.4 & 11.1 & 0.69
\end{tabular}

${ }^{a}$ Morphometric properties of cells in which galanin $(n=18)$ or nNOS $(n=15)$ was detected. In all cases, mean values are shown. Soma depth is expressed as the percentage distance along the dorsoventral axis, with the dorsa white matter defined as $0 \%$ and the lamina II/III border as $100 \%$. For both dendrites and axons, "extent" indicates the dimensions of the entire dendritic or axonal tree and "length" refers to the summed length of individual dendritic or axonal branches. RC:DV ratios were determined from the dorsoventral and rostrocaudal lengths of axons and dendrites. ${ }^{*} p<0.05$ ** $p<0.01$. 

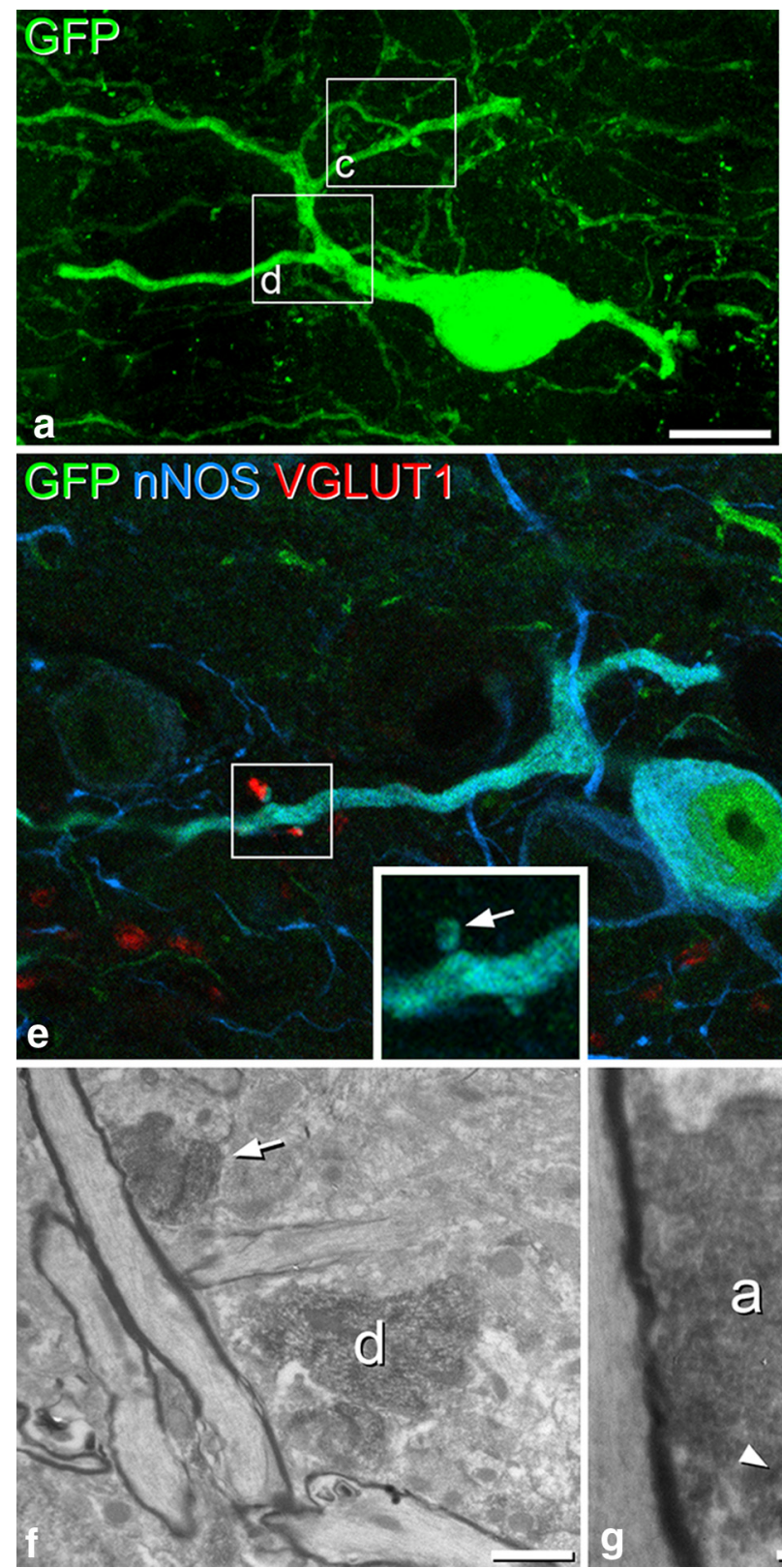
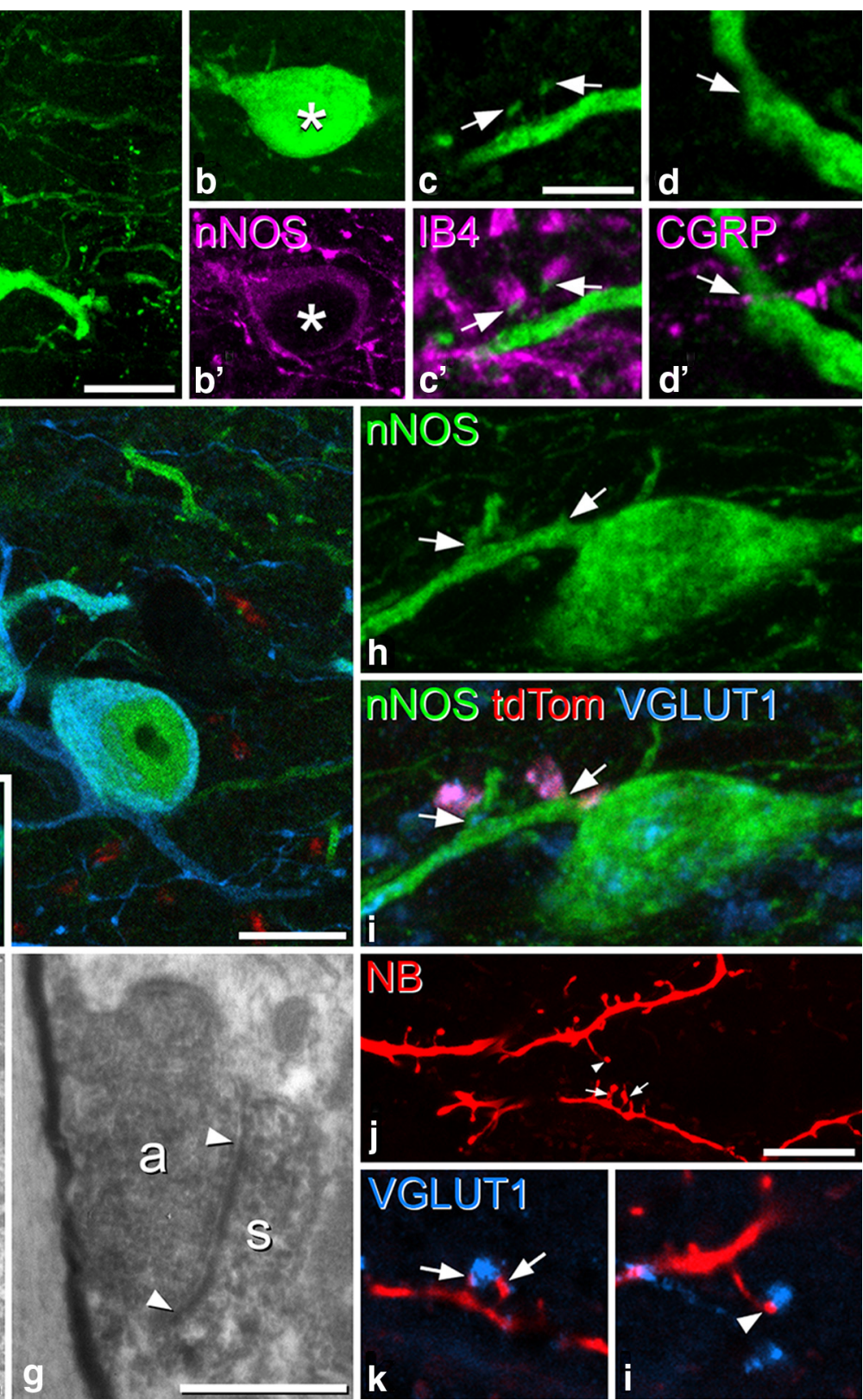

Figure 7. Anatomical evidence for primary afferent input to PrP-GFP and nNOS cells. $\boldsymbol{a}$, Confocal image through a PrP-GFP cell in a parasagittal section from perfusion-fixed tissue. The scan shows GFP (green). Boxes represent the location of parts c and d. $\boldsymbol{b}$ - $\boldsymbol{d}$, Parts of the field shown in $\boldsymbol{a}$, scanned to reveal nNOS, IB4, and CGRP, respectively (all shown in magenta). The soma shows weaknNOS immunoreactivity, surrounding the nucleus $\left({ }^{*}\right)$. c, Two nearby dendritic spines belonging to the cell are in contact with IB4 ${ }^{+}$boutons, which lack CGRP (data not shown). $\boldsymbol{d}$, A small CGRP ${ }^{+}$bouton contacts the dendritic shaft of the cell. $\boldsymbol{e}$, Projection of a short series of confocal images through a PrP-GFP cell that was processed for combined confocal and electron microscopy. The cell contains both GFP (green) and nNOS (blue) immunoreactivity, and a dendritic spine (marked with an arrow in the inset) receives a contact from a VGLUT1-immunoreactive (red) axonal bouton. $\boldsymbol{f}, \boldsymbol{g}$, Electron microscope images (the field shown in $\boldsymbol{f}$ corresponds to the box in $\boldsymbol{e}$ ). The DAB reaction product labels both GFP ${ }^{+}$and VGLUT1 ${ }^{+}$structures.f, Part of the dendritic shaft (d) can be seen together with the dendritic spine (arrow) and adjacent VGLUT1-immunoreactive axonal bouton. $\boldsymbol{g}$, Higher-magnification EM image taken after tilting of the section shows an asymmetrical synapse between the axonal bouton (a) and the dendritic spine (s). $\boldsymbol{h}$, Confocal images to show part of a lamina II nNOS-immunoreactive (green) cell in one of the RetCreER ${ }^{+}$;Ai34 ${ }^{+}$mice. The dendrite that emerges from the cell body has 2 spines (arrows). $\boldsymbol{i}$, The same field scanned to reveal nNOS, tdTomato (red), and VGLUT1 (blue). The spines receive contacts from boutons that express tdTomato and are immunoreactive for VGLUT1, and therefore appear magenta.j, Part of the dendritic tree of the PrP-GFP neuron shown in Figure 3a, with neurobiotin (NB) shown in red. This cell had an axon that entered lamina I and showed increased mEPSC frequency during bath application of capsaicin. $\boldsymbol{k}, \boldsymbol{I}$, Spines belonging to the cell (arrows and arrowhead) received contacts from VGLUT1immunoreactive (blue) boutons. Confocal images are either single optical sections $(\boldsymbol{d}, \boldsymbol{k}, \boldsymbol{I})$ or projections of $36(\boldsymbol{a}), 5(\boldsymbol{b}, \boldsymbol{c}), 3(\boldsymbol{e}), 13(\boldsymbol{h}, \boldsymbol{i})$, or $7(\boldsymbol{j})$ optical sections at $0.5 \mu \mathrm{m} z$-separation. Scale bars: $\boldsymbol{a}$ (also for parts $\boldsymbol{b}, \boldsymbol{j}), 10 \mu \mathrm{m} ; \boldsymbol{c}$ (also for parts $\boldsymbol{d}, \boldsymbol{h}, \boldsymbol{i}, \boldsymbol{k}, \boldsymbol{I}), 5 \mu \mathrm{m} ; \boldsymbol{e}, 10 \mu \mathrm{m} ; \boldsymbol{f}, 1 \mu \mathrm{m} ; \boldsymbol{g}, 0.5 \mu \mathrm{m}$.

dendrites in lamina II, in most cases (48 of 81 ) these extended into lamina III, and occasionally (7 of 81 ) into lamina I. In their original study, Hantman et al. (2004) reported that the PrP-GFP neurons corresponded to central cells, which have a dendritic arbor that extends mainly in the RC direction, but is much shorter than that of islet cells, and with limited distribution in the
ML and DV planes (Grudt and Perl, 2002; Yasaka et al., 2007). Based on a cluster analysis of morphometric data obtained from lamina II neurons in the rat, Yasaka et al. (2007) defined central cells as those in which the ratio of the RC:DV extent of the dendritic tree was $>3.5$ and the RC length was $<400 \mu \mathrm{m}$. We therefore plotted the RC:DV extent of dendritic trees of the recorded 
neurons and found that very few of these had ratios that were $>3.5$ (Fig. $5 a$ ). Although this definition may not be directly applicable to central cells in the mouse, it is clear from the scatter plot that many of the PrP-GFP cells did not have the relatively elongated $\mathrm{RC}$ dendritic trees that are characteristic of central cells (e.g., those illustrated in Fig. $4 b, e$ ).

To provide further information on dendritic length and orientation, we created polar histograms for each cell. These represent the lengths of dendrite that lie within specific ranges (bins) of orientation when the drawing of the cell is projected onto the plane of section, and an example is shown in Figure $5 b$. To allow comparison of dendritic orientation for all cells in the sample, we measured the ratio of dendrite length within specific sets of bins for each cell. This was done by pooling the dendritic lengths in the bins corresponding to angles between $45^{\circ}$ $135^{\circ}$ and $225-315^{\circ}$ (Fig. 5b, dark blue), which represent mainly $\mathrm{RC}$ spread, and pooling those in bins corresponding to angles between $315^{\circ}-45^{\circ}$ and $135^{\circ}-225^{\circ}$ (Fig. 5b, light blue), which represent mainly DV spread. If the ratio RC:DV is $>1$, this indicates a predominantly $\mathrm{RC}$ orientation of dendrites for the cell. As can be seen from the scatter plot in Figure $5 c$, the dendritic orientation of most of the reconstructed cells was mainly along the $\mathrm{RC}$ axis, but this was variable between neurons, and total dendritic lengths (the sum of RC and DV) also varied considerably. Together, these findings show that the PrP-GFP cells are morphologically heterogeneous and that most cannot be classified as central cells.

Although all of the cells had dendritic spines, the density varied considerably (mean 6.8 spines/100 $\mu \mathrm{m}$ length of dendrite, range $0.9-16.3$; Fig. $5 d$ ). For 18 of the cells, mEPSC frequency had been measured while recording at room temperature, and we found that this was strongly correlated with spine density (Fig. 5e; $\mathrm{R}_{\mathrm{S}}=0.84, p<0.001$; Spearman's rank order correlation test). This indicates that differences in spine density account for much of the variability in mEPSC frequency between cells and is consistent with the idea that a substantial part of the excitatory synaptic input to these cells is located on dendritic spines.

The axonal arbors of the 87 reconstructed neurons were orientated mainly along the RC axis, and for nearly all cells they were more extensive than the dendritic tree (Fig. $5 f$ ). The axons generally had limited ML extent (mean $80 \mu \mathrm{m}$, range 28-301 $\mu \mathrm{m})$. However, in most cases, there was significant DV spread, such that nearly all of the cells (84 of 87 ) had axonal boutons in lamina I and/or lamina III (Table 2). Fiftythree of the cells $(71 \%)$ had an axon that entered lamina I, and $30(34 \%)$ gave rise to at least 20 boutons within this lamina. The mean bouton density was $10.9 \pm 2.8(\mathrm{SD})$ per $100 \mu \mathrm{m}$ of axon length, and the total number of boutons identified was 39,817 (mean 458, range 75-1376 boutons per cell), of which
$4 \%$ were in lamina I, $37 \%$ in lamina IIo, 35\% in lamina IIi, and $23 \%$ in lamina III. Therefore, although lamina II is the main target for axons of the PrP-GFP cells (Hantman et al., 2004), they provide significant input to the adjacent laminae.

Of the 72 cells that were tested for nNOS and galanin immunoreactivity, 15 were immunoreactive for nNOS, 18 for galanin, and none for both (Fig. 6). The remaining 39 cells (54\%) were not labeled with either antibody. We have previously shown in perfusion-fixed tissue that $98 \%$ of PrP-GFP cells express nNOS and/or galanin, with $35 \%$ having only nNOS, $28 \%$ only galanin, and 35\% both nNOS and galanin (Iwagaki et al., 2013). Our failure to detect either type of immunoreactivity in many of the tested cells almost certainly resulted from loss of nNOS and/or galanin during the whole-cell recording, and this limited the extent to which we could classify the recorded cells using neurochemical criteria. However, consistent with our previous report (Iwagaki et al., 2013), we found that the cell bodies of the galaninimmunoreactive cells were located more dorsally than those of the nNOS-immunoreactive cells. To compensate for variations in the thickness of the superficial dorsal horn in different slices, we expressed the DV location as a percentage of the distance from the dorsal white matter to the lamina II-III border. The mean value for galanin ${ }^{+}$cells was $61 \%$ and that for $\mathrm{nNOS}^{+}$cells was $83 \%$, and these differed significantly ( $t$ test, $p<0.05$ ). Comparison of dendritic and axonal measures between the $\mathrm{nNOS}^{+}$and galanin ${ }^{+}$cells (Fig. 5; Table 3 ) revealed that the $\mathrm{nNOS}^{+}$cells had significantly greater dendritic extent in all 3 axes, and greater axonal extent in DV and ML axes. 

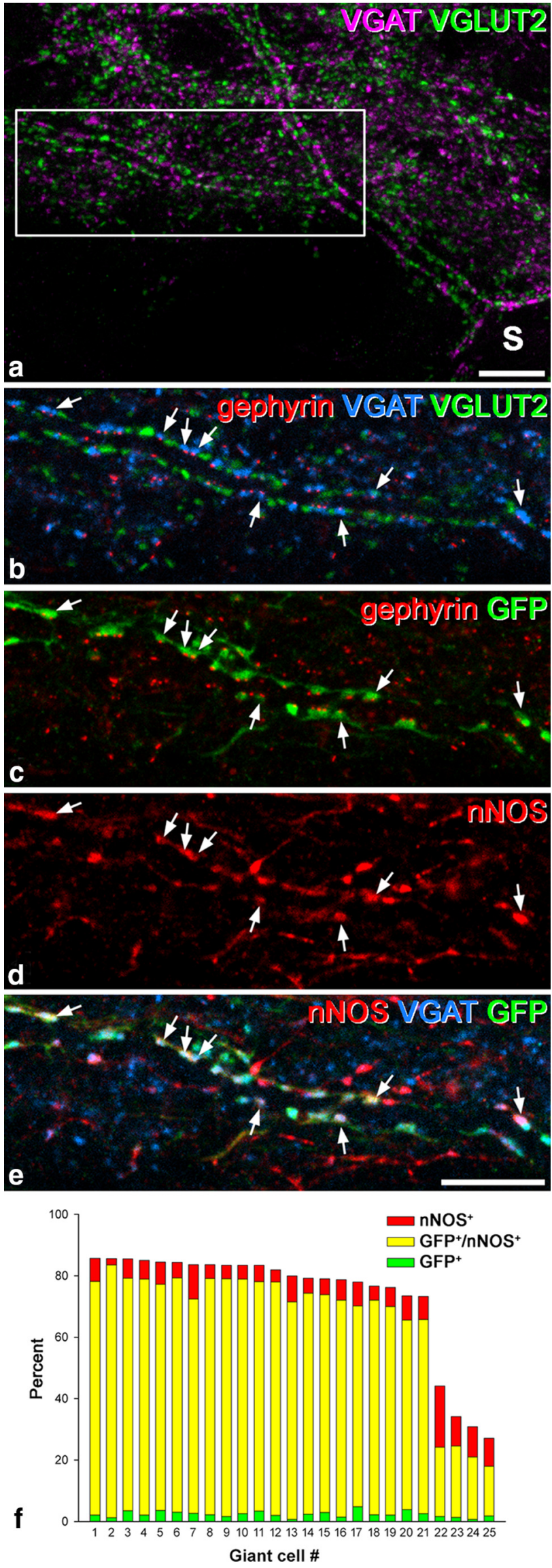

Electrophysiological data were available for 10 of the $\mathrm{nNOS}^{+}$ and 10 of the galanin ${ }^{+}$cells, although two of the galanin ${ }^{+}$cells were among those defined as unresponsive. The only significant differences between the two groups were the input resistances $(631.8 \pm 83.0 \mathrm{M} \Omega$ for $n N O S$ cells, $1142.6 \pm 226.0 \mathrm{M} \Omega$ for galanin cells, $n=10$ for both groups; $t$ test, $p<0.05$; Fig. $5 g$ ) and the heights and widths of action potentials $(59.4 \pm 3.2 \mathrm{mV}, 2.8 \pm 0.4$ ms for nNOS cells, $n=10 ; 46.6 \pm 2.8 \mathrm{mV}, 4.0 \pm 0.2 \mathrm{~ms}$ for galanin cells, $n=8$; $t$ test, $p<0.05$; Fig. $5 g$ ). The smaller input resistance of the nNOS cells is consistent with the finding that they had significantly larger dendritic trees.

\section{Contacts from putative primary}

\section{afferents}

On the $10 \mathrm{nNOS}^{+} / \mathrm{GFP}^{+}$cells in perfusion-fixed tissue that were analyzed for contacts from IB4-binding and CGRP-expressing primary afferents, we identified between 10 and 170 dendritic spines (mean 63 per cell), and the dendritic surface area that was analyzed for each cell ranged from 577 to $3527 \mu \mathrm{m}^{2}$ (mean $2002 \mu \mathrm{m}^{2}$ ). All of the cells received contacts from IB4-labeled boutons that lacked CGRP, whereas 8 of the 10 had contacts from CGRP $^{+}$boutons (Fig. $7 a-d)$. The percentages of spines with contacts from IB $4^{+} / \mathrm{CGRP}^{-}$ boutons ranged from $6 \%$ to $30 \%$ (mean $18 \%$ ), whereas the corresponding values for spines with contacts from CGRP ${ }^{+}$boutons were 0\%-20\% (mean 5\%). Contacts from either type of bouton onto dendritic shafts were relatively infrequent: $0-4.1$ (mean 1.6) per $1000 \mu \mathrm{m}^{2}$ for $\mathrm{IB}^{+}{ }^{+} / \mathrm{CGRP}^{-}$boutons and $0-3.5$ (mean $0.6)$ per $1000 \mu \mathrm{m}^{2}$ for $\mathrm{CGRP}^{+}$boutons.

For the $21 \mathrm{nNOS}^{+} / \mathrm{GFP}^{+}$cells that were analyzed for contacts from $\mathrm{VGLUT} 1^{+}$boutons, between 10 and 101 spines were identified within the VGLUT1 plexus in laminae IIi-III (mean 37 per cell). In all cases, at least some of these spines received contacts from VGLUT $1{ }^{+}$boutons (mean 35\%, range 8\%-62\%). To assess whether these contacts were associated with synapses, we performed a combined confocal and EM analysis on 4 PrP-GFP cells that were $\mathrm{nNOS}^{+}$( 2 cells each from 2 mice). In total, 22 contacts between VGLUT1 ${ }^{+}$boutons and dendritic spines of these cells were identified with the EM (4-7 per cell), and asymmetrical synapses could be identified at 21 (95\%) of these contacts (Fig. $7 e-g)$.

To look for possible input from $\mathrm{A} \beta$ afferents, we used tissue from $\operatorname{RetCreER}{ }^{+} ; \mathrm{Ai34}^{+}$mice, in which tdTomato labels axon terminals of $\mathrm{A} \beta$ fibers that innervate hair follicles or Meissner's corpuscles (Luo et al., 2009). Because these mice did not express GFP under control of the prion promoter, we selected cells in lamina IIi with strong nNOS immunoreactivity, as we have found

\section{$\longleftarrow$}

Figure 9. Selective innervation of lamina I giant cells by GFP axons in the PrP-GFP mouse. $\boldsymbol{a}$, Part of the soma (s) and dendrites of a giant cell seen in a horizontal section through lamina I of a perfusion-fixed mouse. The section was stained with antibodies against VGAT, VGLUT2, GFP, $\mathrm{nNOS}$, and gephyrin, and this image is a projection of 24 optical sections at $0.3 \mu \mathrm{m} z$-spacing. The cell is outlined by numerous VGAT- and VGLUT2-expressing boutons. $\boldsymbol{b}$ - $\boldsymbol{e}$, Highermagnification view of the region indicated by the box in $\boldsymbol{a}$ in projections of 3 optical sections. $\boldsymbol{b}$, The VGAT boutons in contact with the dendrite are associated with gephyrin puncta, indicating that these are sites of inhibitory synapses. $\boldsymbol{c}-\boldsymbol{e}$, The images reveal that many of these VGAT boutons contain both GFP and nNOS (some marked with arrows). $f$, Quantitative data for the inhibitory input to 25 lamina I giant cells. Each of these is shown in a separate column, and the vertical axis represents the percentage of the VGAT boutons apposed to gephyrin puncta on the cell that were immunoreactive for nNOS and/or GFP. The cells are ranked in decreasing order of the percentage of labeled boutons. For the great majority ( 21 of 25 cells), well over half of the inhibitory input is derived from boutons that contained both GFP and nNOS. Scale bars: $\boldsymbol{a}, \boldsymbol{b}-\boldsymbol{e}$, $10 \mu \mathrm{m}$. 
that the majority of these cells express GFP in the PrP-GFP mouse. We identified between 13 and 37 spines on each of the 6 cells analyzed (mean 25 per cell) and found that $10 \%$ of these $(3 \%-15 \%)$ received contacts from tdTomato ${ }^{+} /$ VGLUT1 ${ }^{+}$boutons (Fig. $7 h, i$ ).

Between 26 and 93 (mean 68) dendritic spines in laminae IIi-III were identified on the 6 recorded PrP-GFP neurons that were assessed for anatomical evidence of VGLUT1 contacts, and all of these cells received contacts from VGLUT1-immunoreactive boutons (Fig. $7 j-l)$. For the two capsaicin-responsive cells, 12 and 10 contacts were identified, and this corresponded to $15 \%$ and $39 \%$ of the spines analyzed, respectively. For the 5 cells with axons that arborized in lamina I, between 7 and 31 contacts were identified, corresponding to $14 \%-29 \%$ (mean $28 \%$ ) of the spines.

Fos expression in response to capsaicin In the $3 \operatorname{PrP}$-GFP mice that had received intraplantar injection of capsaicin, numerous Fos ${ }^{+}$cells were present in the medial part of the L4 segment. We identified 40-51 $\mathrm{GFP}^{+}$cells (mean 45) within this region in these animals, of which 61\%-73\% (mean 69\%) were nNOS-immunoreactive. Despite the presence of numerous Fos ${ }^{+}$neurons, only $6 \%$ $(0 \%-11 \%)$ of the $\mathrm{nNOS}^{+} / \mathrm{GFP}^{+}$cells were Fos-immunoreactive (Fig. 8). Interestingly, although only a few nNOS $^{-} /$ $\mathrm{GFP}^{+}$cells were sampled in these sections (11-17 cells, mean 14), approximately onethird of these were Fos-immunoreactive ( $9 \%$ $43 \%$, mean $29 \%$ ).

\section{Postsynaptic targets of PrP-GFP axons} in lamina I

Because the axons of some PrP-GFP cells were found to give rise to numerous boutons in lamina I, we first determined the proportion of VGAT boutons in this lamina that contained GFP, and then looked for evidence that these were presynaptic to projection neurons, which are concentrated in this lamina (Todd, 2010).

A total of 100 VGAT boutons were identified in the transverse sections from each of $4 \mathrm{PrP}-G F P$ mice, and $9 \pm 2.2 \%$ (SD) of these were GFP-immunoreactive. The mean $z$-axis lengths of those with and without GFP were $0.99 \mu \mathrm{m}$ and $0.95 \mu \mathrm{m}$, and these values did not differ significantly (Mann-Whitney $U$ test, $p=0.2$ ), indicating that our estimate was unlikely to have been biased due to difference in $z$-axis lengths between the two groups.

Examination of horizontal sections through lamina I that had been reacted with antibodies against VGLUT2, VGAT, gephyrin, GFP, and nNOS revealed that, as in the rat (Puskár et al., 2001; Polgár et al., 2008), there is a sparse but distinctive population of large neurons with cell bodies and dendrites that are outlined by both VGAT- and VGLUT2-immunoreactive boutons (Fig. 9a), which we have named "giant cells" (Todd, 2010). The VGAT ${ }^{+}$ boutons that surrounded these cells were associated with gephyrin puncta, which indicates that these were forming inhibitory synapses (Fig. 9b). Twenty-five of these cells were identified (7-9 in each of 3 mice), and between 104 and 509 (mean 234) VGAT boutons that were associated with gephyrin puncta were identified on each cell. For most ( 21 of 25) of these cells, the majority of these $\mathrm{VGAT}^{+}$boutons contained GFP and/or nNOS (in most cases both), and these accounted for between $62 \%$ and $82 \%$ of the $\mathrm{VGAT}^{+}$boutons that contacted gephyrin puncta on the cells (Fig. $9 c-f$ ). Although the remaining 4 cells also received contacts at gephyrin puncta from $\mathrm{VGAT}^{+}$boutons that contained GFP and/or nNOS, these accounted for a much smaller proportion of the inhibitory synapses $(27 \%-44 \%)$. This indicates that, as in the rat, lamina I giant cells are selectively targeted by nNOScontaining axons and the great majority of these are derived from PrP-GFP cells.

The majority of lamina I projection neurons in rat express the NK1r; and although the receptor is also present on some excitatory interneurons, these show only weak expression (Al Ghamdi et al., 2009). This suggests that cells in this lamina with strong NK1r expression are likely to be projection neurons. We there- 


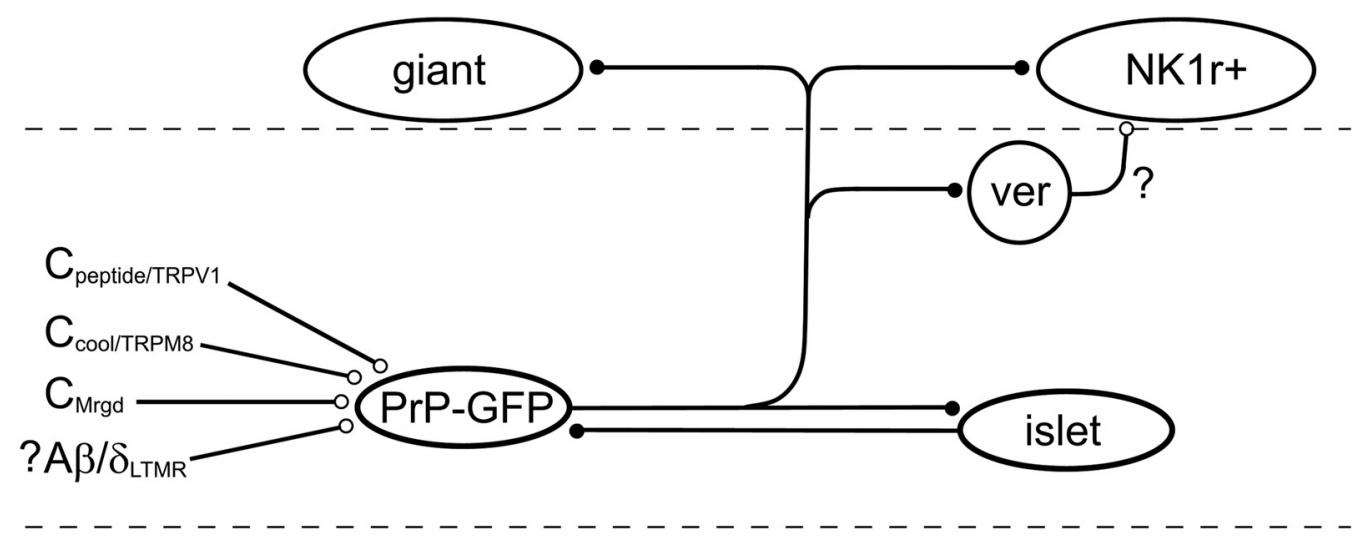

Figure 11. Schematic diagram summarizing the inputs to and outputs from the PrP-GFP cells. Results from the present study suggest that these cells are innervated by several types of unmyelinated primary afferent, including peptidergic ( fiber nociceptors that express TRPV1, cooling-responsive (TRPM8 ${ }^{+}$) fibers, and nonpeptidergic ( nociceptors that express Mrgd. In addition, they appear to be innervated directly by A $\beta / A \delta$ LTMR afferents, although this is shown with a question mark, as it is not clear whether these form functional synapses. Some of these cells have axons that enter lamina I, where they preferentially innervate giant cells and some NK1r ${ }^{+}$neurons. However, all of the cells also have extensive axonal arborizations in lamina II, and these are thought to include inhibitory islet cells (with which they make reciprocal connections) and excitatory vertical cells (data from Zheng et al., 2010). Vertical cells in lamina II can form synapses on NK1 ${ }^{+}$ neurons in lamina I (Lu and Perl, 2005); however, it is not known whether these include those cells that are directly innervated by the PrP-GFP cells, and so this connection is shown with a question mark. Dashed lines indicate the borders of lamina II.

fore selected 60 lamina I cells with strong NK1r immunoreactivity in horizontal sections that had been reacted with antibodies against GFP, NK1r, VGAT, and gephyrin. Because of limitations in the availability of primary antibodies raised in appropriate species, we were not able to include anti-nNOS in these reactions. Because the NK1r outlines the soma and dendrites of these cells, it was possible to identify inhibitory synapses by the presence of VGAT boutons that contacted the plasma membrane at sites corresponding to gephyrin puncta (Polgár et al., 2011). Virtually all of the gephyrin puncta on the $60 \mathrm{NK} 1 \mathrm{r}^{+}$cells were associated with VGAT boutons. The density of the puncta varied between cells but was always lower than that seen on the giant cells. Between 33 and 604 (mean 101) VGAT boutons that contacted gephyrin puncta were analyzed on each cell, and in all but one case, at least some of these boutons were GFP ${ }^{+}$(Fig. 10a-d). However, the proportion varied considerably and appeared to be bimodally distributed, such that although for most (42 of 60) of the cells GFP was present in $<20 \%$ of the VGAT boutons that synapsed on them, for 18 cells the proportion of VGAT boutons with GFP was considerably higher (25\%-62\%) (Fig. 10e).

\section{Discussion}

The main findings of this study are the following: (1) PrP-GFP cells are morphologically heterogeneous and seldom correspond to central cells; (2) some receive synaptic input from VGLUT1 ${ }^{+}$ boutons that are likely to be A-LTMRs; (3) although most respond to bath-applied capsaicin, those that contain nNOS rarely upregulate Fos after intraplantar capsaicin; and (4) some have axons that enter lamina I, where their targets include both giant cells and $\mathrm{NK} 1 \mathrm{r}^{+}$neurons.

\section{Classification of inhibitory interneurons}

One of the main limitations to our understanding of the neuronal circuitry for processing nociceptive and pruriceptive information in the dorsal horn is the diversity of the interneurons, and the difficulty in assigning them to distinct functional populations. Certain morphological classes can be recognized in lamina II, for example, inhibitory islet cells, and excitatory vertical and radial cells (Lu and Perl, 2003, 2005; Heinke et al., 2004; Maxwell et al., 2007; Yasaka et al., 2010; Punnakkal et al., 2014). However, al- though Hantman et al. (2004) described the PrP-GFP cells as central cells, our reconstructions of their dendritic trees revealed that, although they were never islet cells, they were morphologically heterogeneous and in most cases did not correspond to central cells.

An alternative, neurochemical scheme has identified four largely nonoverlapping populations of inhibitory interneurons, based on expression of parvalbumin, NPY, galanin, and nNOS (Polgár et al., 2013b). Between them, these account for over half the GABAergic neurons in laminae I-II, and they differ both in their responses to noxious stimuli (Polgár et al., 2013b) and in their postsynaptic targets (Polgár et al., 2011; Hughes et al., 2012). Although there is almost complete separation of the nNOS and galanin populations in rat (Polgár et al., 2013b), there is some overlap in mouse (Iwagaki et al., 2013; Kardon et al., 2014). We have shown that PrP-GFP cells are contained within the galaninand nNOS-expressing populations, accounting for $57 \%$ of those expressing only nNOS, $23 \%$ of those expressing only galanin, and $83 \%$ of those with both nNOS and galanin (Iwagaki et al., 2013). nNOS- and galanin-expressing inhibitory interneurons also have other features in common because both express $s_{2} t_{2 \mathrm{~A}}$ and are dependent on Bhlhb5 (Kardon et al., 2014). However, in the rat, they differ considerably in their responses to noxious stimuli (Polgár et al., 2013b). Although we could not unequivocally assign the recorded cells to these neurochemical classes, it is likely that there are morphological differences between them because the galanin-immunoreactive cells were located more dorsally and had smaller dendritic trees and axons that were more restricted in the DV and ML axes. This suggests that the PrP-GFP cells do not form a homogeneous population.

\section{Primary afferent inputs}

Hantman et al. (2004) reported that PrP-GFP cells showed increased mEPSC frequency following bath application of capsaicin, indicating that they received monosynaptic input from TRPV1-expressing nociceptive afferents. However, surprisingly, we found that nNOS-immunoreactive GABAergic lamina II neurons in the rat seldom showed Fos after intraplantar capsaicin (Polgár et al., 2013b). In agreement with these two studies, we observed that capsaicin increased mEPSC frequency of PrP-GFP cells, but that those with nNOS immunoreactivity seldom ex- 
pressed Fos following intraplantar capsacin injection. The resolution of this paradox seems to be that, while the cells do receive input from TRPV1-expressing afferents, this is at a low density because the increase in mEPSC frequency was very modest $(\sim 3$ $\mathrm{Hz}$ increase in the presence of $2 \mu \mathrm{M}$ capsaicin) and much smaller than has been seen for other neuronal populations recorded at room temperature. For example, Baccei et al. (2003) found that $2 \mu \mathrm{M}$ capsaicin increased mEPSC frequency by $\sim 40 \mathrm{~Hz}$ in unidentified lamina II neurons of P9-P10 rats, whereas Dickie and Torsney (2014) reported mean changes of $\sim 20 \mathrm{~Hz}$ following application of $1 \mu \mathrm{M}$ capsaicin to lamina I NK1r-expressing neurons. Consistent with this interpretation, we found that, while the $\mathrm{nNOS}^{+}$PrP-GFP cells received contacts from peptidergic primary afferents, which largely correspond to those that express TRPV1 (Cavanaugh et al., 2011), this was at a low density.

All of the cells examined in perfusion-fixed tissue also received contacts from IB $4^{+} / \mathrm{CGRP}^{-}$boutons, which correspond to unmyelinated nonpeptidergic (Mrgprd ${ }^{+}$) cutaneous nociceptors (Zylka et al., 2005), and it is likely that many of these contacts represent synaptic inputs. The persistence of icilin-evoked responses in the presence of the TRPA1 blocker A967079 confirms that some of the cells are also innervated by TRPM8-expressing (cooling-sensitive) afferents. Because the Mrgprd ${ }^{+}, \mathrm{TRPV}^{+}$, and TRPM $8{ }^{+}$afferents are thought to belong to largely nonoverlapping subsets (Staaf et al., 2010; Cavanaugh et al., 2011), this suggests that the PrP-GFP cells are innervated by several classes of unmyelinated afferent.

Our anatomical results suggest that the nNOS-expressing PrP-GFP cells receive synapses from A-LTMRs, including some with $A \beta$ axons. The failure to detect monosynaptic $A$-fiber inputs in most recorded cells, which is consistent with the results of Hantman et al. (2004), may be because these form functionally silent synapses (Bardoni et al., 1998). However, it is also possible that most of these synapses were from axons that had been severed during the slice preparation, due to their complex course through the dorsal horn (Abraira and Ginty, 2013). At least some of the cells appear to be activated polysynaptically by $\mathrm{A} \beta$ afferents.

Together, these results indicate that PrP-GFP cells are innervated by a wide range of primary afferents, including nociceptors, thermoreceptors, and probably also myelinated mechanoreceptors, and that there is convergence of modalities onto individual cells (Fig. 11).

\section{Axonal projections to lamina I}

Although Hantman et al. (2004) reported that PrP-GFP cell axons were restricted to lamina II, we found that over half of these cells had an axon that entered lamina I, and that GFP axons accounted for nearly $10 \%$ of the GABAergic boutons in this lamina. We previously identified a population of giant lamina I projection neurons in the rat that were selectively innervated by nNOS-immunoreactive GABAergic axons (Puskár et al., 2001; Polgár et al., 2008). Here we show that the corresponding cells in the mouse are densely innervated by the PrP-GFP cells, which provide the majority of their inhibitory input. In addition, some lamina I cells with strong NK1r expression (putative projection neurons) also received a substantial proportion of their inhibitory synapses from PrP-GFP axons. Interestingly, all of the PrP-GFP cells that projected to lamina I also had extensive arbors in lamina II; therefore, even those that innervate these lamina I neurons must have additional postsynaptic targets (Fig. 11).
The loss of nNOS- and galanin-expressing cells in the $B h l h b 5^{-/-}$mouse suggests that one or both populations are responsible for the increased itch, and loss of relief by counterstimulation, that is seen in these mice (Kardon et al., 2014). However, Duan et al. (2014) have recently reported that ablation of inhibitory interneurons expressing dynorphin, which correspond to the galanin ${ }^{+}$population (Bröhl et al., 2008; Sardella et al., 2011b), results in mechanical allodynia, but not increased itch. This suggests that loss the of nNOS-expressing inhibitory interneurons may underlie the increased itch in Bhlhb5 $5^{-/-}$mice. The rapid inhibition of itch by counterstimuli appears to involve both GABA and glycine (Akiyama et al., 2011), and the nNOS cells, which are thought to release both transmitters (Todd, 2010), could suppress itch by inhibiting projection neurons and/or excitatory interneurons in the itch pathway. NK1rexpressing lamina I neurons have been implicated in itch (Carstens et al., 2010), and we have found that some retrogradely labeled giant lamina I cells in mouse express Fos following intradermal injection of chloroquine (A.J.T. and E.P., unpublished data). It is therefore likely that the powerful inhibitory input to lamina I projection neurons provided by the $\mathrm{nNOS}^{+}$PrP-GFP cells contributes to prevention of itch, and their axonal projections to lamina II may also target itch-activated interneurons. Consistent with this suggestion, we observed that very few $s_{2} t_{2}$-expressing (inhibitory) $\mathrm{nNOS}^{+}$interneurons were Fos-immunoreactive following intradermal chloroquine injection (A.J.T. and E.P., unpublished data). The diversity of sensory inputs to the PrP-GFP cells is generally consistent with the range of effective counterstimuli that suppress itch, which include a variety of noxious and thermal stimuli (Ross, 2011; Akiyama and Carstens, 2013), as well as activation of TRPM8 receptors by menthol (Kardon et al., 2014). However, the finding of synaptic input from putative A-LTMRs seems to be at odds with this interpretation because innocuous tactile stimuli do not apparently inhibit itch. It is possible that, despite the presence of direct synaptic input, the A-LTMR afferents are not able to drive the nNOS ${ }^{+}$cells at sufficiently high rates to suppress itch (e.g., if these afferents also generate feedforward inhibition of the $\mathrm{nNOS}^{+}$cells).

An alternative possibility is that the nNOS-expressing inhibitory interneurons have a role in suppressing pain transmission and contribute both to limiting the intensity of pain during noxious stimulation through their input from nociceptors (Sandkühler, 2009) and also to the relief of pain by innocuous stimuli, as proposed in the Gate Theory (Melzack and Wall, 1965).

To distinguish between these mechanisms, it will be necessary in future studies to inactivate the nNOS-expressing inhibitory interneurons and assess the effect on behavior.

\section{References}

Abraira VE, Ginty DD (2013) The sensory neurons of touch. Neuron 79: 618-639. CrossRef Medline

Akiyama T, Carstens E (2013) Neural processing of itch. Neuroscience 250: 697-714. CrossRef Medline

Akiyama T, Iodi Carstens M, Carstens E (2011) Transmitters and pathways mediating inhibition of spinal itch-signaling neurons by scratching and other counterstimuli. PLoS One 6:e22665. CrossRef Medline

Al Ghamdi KS, Polgár E, Todd AJ (2009) Soma size distinguishes projection neurons from neurokinin 1 receptor-expressing interneurons in lamina I of the rat lumbar spinal dorsal horn. Neuroscience 164:1794-1804. CrossRef Medline

Alvarez FJ, Villalba RM, Zerda R, Schneider SP (2004) Vesicular glutamate transporters in the spinal cord, with special reference to sensory primary afferent synapses. J Comp Neurol 472:257-280. CrossRef Medline

Baccei ML, Bardoni R, Fitzgerald M (2003) Development of nociceptive 
synaptic inputs to the neonatal rat dorsal horn: glutamate release by capsaicin and menthol. J Physiol 549:231-242. CrossRef Medline

Bardoni R, Magherini PC, MacDermott AB (1998) NMDA EPSCs at glutamatergic synapses in the spinal cord dorsal horn of the postnatal rat. J Neurosci 18:6558-6567. Medline

Baseer N, Polgár E, Watanabe M, Furuta T, Kaneko T, Todd AJ (2012) Projection neurons in lamina III of the rat spinal cord are selectively innervated by local dynorphin-containing excitatory neurons. J Neurosci 32: 11854-11863. CrossRef Medline

Becker CM, Hoch W, Betz H (1989) Sensitive immunoassay shows selective association of peripheral and integral membrane proteins of the inhibitory glycine receptor complex. J Neurochem 53:124-131. CrossRef Medline

Bernardi PS, Valtschanoff JG, Weinberg RJ, Schmidt HH, Rustioni A (1995) Synaptic interactions between primary afferent terminals and GABA and nitric oxide-synthesizing neurons in superficial laminae of the rat spinal cord. J Neurosci 15:1363-1371. Medline

Braz J, Solorzano C, Wang X, Basbaum AI (2014) Transmitting pain and itch messages: a contemporary view of the spinal cord circuits that generate gate control. Neuron 82:522-536. CrossRef Medline

Bröhl D, Strehle M, Wende H, Hori K, Bormuth I, Nave KA, Müller T, Birchmeier C (2008) A transcriptional network coordinately determines transmitter and peptidergic fate in the dorsal spinal cord. Dev Biol 322:381-393. CrossRef Medline

Carstens EE, Carstens MI, Simons CT, Jinks SL (2010) Dorsal horn neurons expressing NK-1 receptors mediate scratching in rats. Neuroreport 21: 303-308. CrossRef Medline

Cavanaugh DJ, Chesler AT, Bráz JM, Shah NM, Julius D, Basbaum AI (2011) Restriction of transient receptor potential vanilloid-1 to the peptidergic subset of primary afferent neurons follows its developmental downregulation in nonpeptidergic neurons. J Neurosci 31:10119-10127. CrossRef Medline

Daniele CA, MacDermott AB (2009) Low-threshold primary afferent drive onto GABAergic interneurons in the superficial dorsal horn of the mouse. J Neurosci 29:686-695. CrossRef Medline

Dickie AC, Torsney C (2014) The chemerin receptor 23 agonist, chemerin, attenuates monosynaptic C-fibre input to lamina I neurokinin 1 receptor expressing rat spinal cord neurons in inflammatory pain. Mol Pain 10:24. CrossRef Medline

Duan B, Cheng L, Bourane S, Britz O, Padilla C, Garcia-Campmany L, Krashes M, Knowlton W, Velasquez T, Ren X, Ross SE, Lowell BB, Wang Y, Goulding M, Ma Q (2014) Identification of spinal circuits transmitting and gating mechanical pain. Cell 159:1417-1432. CrossRef Medline

Graham BA, Brichta AM, Callister RJ (2007) Moving from an averaged to specific view of spinal cord pain processing circuits. J Neurophysiol 98: 1057-1063. CrossRef Medline

Grudt TJ, Perl ER (2002) Correlations between neuronal morphology and electrophysiological features in the rodent superficial dorsal horn. J Physiol 540:189-207. CrossRef Medline

Guillery RW (2002) On counting and counting errors. J Comp Neurol 447: 1-7. CrossRef Medline

Hantman AW, van den Pol AN, Perl ER (2004) Morphological and physiological features of a set of spinal substantia gelatinosa neurons defined by green fluorescent protein expression. J Neurosci 24:836-842. CrossRef Medline

Heinke B, Ruscheweyh R, Forsthuber L, Wunderbaldinger G, Sandkühler J (2004) Physiological, neurochemical and morphological properties of a subgroup of GABAergic spinal lamina II neurones identified by expression of green fluorescent protein in mice. J Physiol 560:249-266. CrossRef Medline

Herbison AE, Simonian SX, Norris PJ, Emson PC (1996) Relationship of neuronal nitric oxide synthase immunoreactivity to GnRH neurons in the ovariectomized and intact female rat. J Neuroendocrinol 8:73-82. CrossRef Medline

Hughes DI, Scott DT, Todd AJ, Riddell JS (2003) Lack of evidence for sprouting of Abeta afferents into the superficial laminas of the spinal cord dorsal horn after nerve section. J Neurosci 23:9491-9499. Medline

Hughes DI, Sikander S, Kinnon CM, Boyle KA, Watanabe M, Callister RJ, Graham BA (2012) Morphological, neurochemical and electrophysiological features of parvalbumin-expressing cells: a likely source of axoaxonic inputs in the mouse spinal dorsal horn. J Physiol 590:3927-3951. CrossRef Medline
Hunt SP, Mantyh PW (2001) The molecular dynamics of pain control. Nat Rev Neurosci 2:83-91. CrossRef Medline

Iwagaki N, Garzillo F, Polgár E, Riddell JS, Todd AJ (2013) Neurochemical characterisation of lamina II inhibitory interneurons that express GFP in the PrP-GFP mouse. Mol Pain 9:56. CrossRef Medline

Ju G, Hökfelt T, Brodin E, Fahrenkrug J, Fischer JA, Frey P, Elde RP, Brown JC (1987) Primary sensory neurons of the rat showing calcitonin generelated peptide immunoreactivity and their relation to substance P-, somatostatin-, galanin-, vasoactive intestinal polypeptide- and cholecystokinin-immunoreactive ganglion cells. Cell Tissue Res 247:417431. CrossRef Medline

Kardon AP, Polgár E, Hachisuka J, Snyder LM, Cameron D, Savage S, Cai X, Karnup S, Fan CR, Hemenway GM, Bernard CS, Schwartz ES, Nagase H, Schwarzer C, Watanabe M, Furuta T, Kaneko T, Koerber HR, Todd AJ, Ross SE (2014) Dynorphin acts as a neuromodulator to inhibit itch in the dorsal horn of the spinal cord. Neuron 82:573-586. CrossRef Medline

Lu Y, Perl ER (2003) A specific inhibitory pathway between substantia gelatinosa neurons receiving direct C-fiber input. J Neurosci 23:8752-8758. Medline

Lu Y, Perl ER (2005) Modular organization of excitatory circuits between neurons of the spinal superficial dorsal horn (laminae I and II). J Neurosci 25:3900-3907. CrossRef Medline

Luo W, Enomoto H, Rice FL, Milbrandt J, Ginty DD (2009) Molecular identification of rapidly adapting mechanoreceptors and their developmental dependence on ret signaling. Neuron 64:841-856. CrossRef Medline

Makwana M, Werner A, Acosta-Saltos A, Gonitel R, Pararajasingham A, Ruff C, Rumajogee P, Cuthill D, Galiano M, Bohatschek M, Wallace AS, Anderson PN, Mayer U, Behrens A, Raivich G (2010) Peripheral facial nerve axotomy in mice causes sprouting of motor axons into perineuronal central white matter: time course and molecular characterization. J Comp Neurol 518:699-721. CrossRef Medline

Maxwell DJ, Belle MD, Cheunsuang O, Stewart A, Morris R (2007) Morphology of inhibitory and excitatory interneurons in superficial laminae of the rat dorsal horn. J Physiol 584:521-533. CrossRef Medline

Melzack R, Wall PD (1965) Pain mechanisms: a new theory. Science 150: 971-979. CrossRef Medline

Miura E, Fukaya M, Sato T, Sugihara K, Asano M, Yoshioka K, Watanabe M (2006) Expression and distribution of JNK/SAPK-associated scaffold protein JSAP1 in developing and adult mouse brain. J Neurochem 97: 1431-1446. CrossRef Medline

Nakatsuka T, Ataka T, Kumamoto E, Tamaki T, Yoshimura M (2000) Alteration in synaptic inputs through C-afferent fibers to substantia gelatinosa neurons of the rat spinal dorsal horn during postnatal development. Neuroscience 99:549-556. CrossRef Medline

Polgár E, Hughes DI, Riddell JS, Maxwell DJ, Puskár Z, Todd AJ (2003) Selective loss of spinal GABAergic or glycinergic neurons is not necessary for development of thermal hyperalgesia in the chronic constriction injury model of neuropathic pain. Pain 104:229-239. CrossRef Medline

Polgár E, Al-Khater KM, Shehab S, Watanabe M, Todd AJ (2008) Large projection neurons in lamina I of the rat spinal cord that lack the neurokinin 1 receptor are densely innervated by VGLUT2-containing axons and possess GluR4-containing AMPA receptors. J Neurosci 28:1315013160. CrossRef Medline

Polgár E, Sardella TC, Watanabe M, Todd AJ (2011) Quantitative study of NPY-expressing GABAergic neurons and axons in rat spinal dorsal horn. J Comp Neurol 519:1007-1023. CrossRef Medline

Polgár E, Durrieux C, Hughes DI, Todd AJ (2013a) A quantitative study of inhibitory interneurons in laminae I-III of the mouse spinal dorsal horn. PLoS One 8:e78309. CrossRef Medline

Polgár E, Sardella TC, Tiong SY, Locke S, Watanabe M, Todd AJ (2013b) Functional differences between neurochemically defined populations of inhibitory interneurons in the rat spinal dorsal horn. Pain 154:26062615. CrossRef Medline

Ptak K, Burnet H, Blanchi B, Sieweke M, De Felipe C, Hunt SP, Monteau R, Hilaire G (2002) The murine neurokinin NK1 receptor gene contributes to the adult hypoxic facilitation of ventilation. Eur J Neurosci 16:22452252. CrossRef Medline

Punnakkal P, von Schoultz C, Haenraets K, Wildner H, Zeilhofer HU (2014) Morphological, biophysical and synaptic properties of glutamatergic neurons of the mouse spinal dorsal horn. J Physiol 592:759-776. CrossRef Medline

Puskár Z, Polgár E, Todd AJ (2001) A population of large lamina I projec- 
tion neurons with selective inhibitory input in rat spinal cord. Neuroscience 102:167-176. CrossRef Medline

Ribeiro-da-Silva A, Coimbra A (1982) Two types of synaptic glomeruli and their distribution in laminae I-III of the rat spinal cord. J Comp Neurol 209:176-186. CrossRef Medline

Ross SE (2011) Pain and itch: insights into the neural circuits of aversive somatosensation in health and disease. Curr Opin Neurobiol 21:880887. CrossRef Medline

Ross SE, Mardinly AR, McCord AE, Zurawski J, Cohen S, Jung C, Hu L, Mok SI, Shah A, Savner EM, Tolias C, Corfas R, Chen S, Inquimbert P, Xu Y, McInnes RR, Rice FL, Corfas G, Ma Q, Woolf CJ, et al. (2010) Loss of inhibitory interneurons in the dorsal spinal cord and elevated itch in Bhlhb5 mutant mice. Neuron 65:886-898. CrossRef Medline

Ruscheweyh R, Sandkühler J (2002) Lamina-specific membrane and discharge properties of rat spinal dorsal horn neurones in vitro. J Physiol 541:231-244. CrossRef Medline

Sandkühler J (2009) Models and mechanisms of hyperalgesia and allodynia. Physiol Rev 89:707-758. CrossRef Medline

Sardella TC, Polgár E, Watanabe M, Todd AJ (2011a) A quantitative study of neuronal nitric oxide synthase expression in laminae I-III of the rat spinal dorsal horn. Neuroscience 192:708-720. CrossRef Medline

Sardella TC, Polgár E, Garzillo F, Furuta T, Kaneko T, Watanabe M, Todd AJ (2011b) Dynorphin is expressed primarily by GABAergic neurons that contain galanin in the rat dorsal horn. Mol Pain 7:76. CrossRef Medline

Staaf S, Franck MC, Marmigère F, Mattsson JP, Ernfors P (2010) Dynamic expression of the TRPM subgroup of ion channels in developing mouse sensory neurons. Gene Expr Patterns 10:65-74. CrossRef Medline

Takamori S, Riedel D, Jahn R (2000) Immunoisolation of GABA-specific synaptic vesicles defines a functionally distinct subset of synaptic vesicles. J Neurosci 20:4904-4911. Medline

Todd AJ (2010) Neuronal circuitry for pain processing in the dorsal horn. Nat Rev Neurosci 11:823-836. CrossRef Medline

Todd AJ, Spike RC, Polgár E (1998) A quantitative study of neurons which express neurokinin- 1 or somatostatin sst2a receptor in rat spinal dorsal horn. Neuroscience 85:459-473. CrossRef Medline

Todd AJ, McGill MM, Shehab SA (2000) Neurokinin 1 receptor expression by neurons in laminae I, III and IV of the rat spinal dorsal horn that project to the brainstem. Eur J Neurosci 12:689-700. CrossRef Medline

Todd AJ, Puskar Z, Spike RC, Hughes C, Watt C, Forrest L (2002) Projection neurons in lamina I of rat spinal cord with the neurokinin 1 receptor are selectively innervated by substance P-containing afferents and respond to noxious stimulation. J Neurosci 22:4103-4113. Medline

Todd AJ, Hughes DI, Polgár E, Nagy GG, Mackie M, Ottersen OP, Maxwell DJ (2003) The expression of vesicular glutamate transporters VGLUT1 and VGLUT2 in neurochemically defined axonal populations in the rat spinal cord with emphasis on the dorsal horn. Eur J Neurosci 17:13-27. CrossRef Medline

Torsney C (2011) Inflammatory pain unmasks heterosynaptic facilitation in lamina I neurokinin 1 receptor-expressing neurons in rat spinal cord. J Neurosci 31:5158-5168. CrossRef Medline
Torsney C, MacDermott AB (2006) Disinhibition opens the gate to pathological pain signaling in superficial neurokinin 1 receptor-expressing neurons in rat spinal cord. J Neurosci 26:1833-1843. CrossRef Medline

Usoskin D, Furlan A, Islam S, Abdo H, Lonnerberg P, Lou D, HjerlingLeffler J, Haeggström J, Kharchenko O, Kharchenko PV, Linnarsson S, Ernfors P (2015) Unbiased classification of sensory neuron types by large-scale single-cell RNA sequencing. Nat Neurosci 18:145-153. CrossRef Medline

Uta D, Furue H, Pickering AE, Rashid MH, Mizuguchi-Takase H, Katafuchi T, Imoto K, Yoshimura M (2010) TRPA1-expressing primary afferents synapse with a morphologically identified subclass of substantia gelatinosa neurons in the adult rat spinal cord. Eur J Neurosci 31:1960-1973. CrossRef Medline

Valtschanoff JG, Weinberg RJ, Rustioni A (1992) NADPH diaphorase in the spinal cord of rats. J Comp Neurol 321:209-222. CrossRef Medline

van den Pol AN, Ghosh PK, Liu RJ, Li Y, Aghajanian GK, Gao XB (2002) Hypocretin (orexin) enhances neuron activity and cell synchrony in developing mouse GFP-expressing locus coeruleus. J Physiol 541:169-185. CrossRef Medline

Wang H, Zylka MJ (2009) Mrgprd-expressing polymodal nociceptive neurons innervate most known classes of substantia gelatinosa neurons. J Neurosci 29:13202-13209. CrossRef Medline

Wrigley PJ, Jeong HJ, Vaughan CW (2009) Primary afferents with TRPM8 and TRPA1 profiles target distinct subpopulations of rat superficial dorsal horn neurones. Br J Pharmacol 157:371-380. CrossRef Medline

Yang K, Kumamoto E, Furue H, Yoshimura M (1998) Capsaicin facilitates excitatory but not inhibitory synaptic transmission in substantia gelatinosa of the rat spinal cord. Neurosci Lett 255:135-138. CrossRef Medline

Yasaka T, Kato G, Furue H, Rashid MH, Sonohata M, Tamae A, Murata Y, Masuko S, Yoshimura M (2007) Cell-type-specific excitatory and inhibitory circuits involving primary afferents in the substantia gelatinosa of the rat spinal dorsal horn in vitro. J Physiol 581:603-618. CrossRef Medline

Yasaka T, Tiong SY, Hughes DI, Riddell JS, Todd AJ (2010) Populations of inhibitory and excitatory interneurons in lamina II of the adult rat spinal dorsal horn revealed by a combined electrophysiological and anatomical approach. Pain 151:475-488. CrossRef Medline

Yoshida T, Fukaya M, Uchigashima M, Miura E, Kamiya H, Kano M, Watanabe M (2006) Localization of diacylglycerol lipase-alpha around postsynaptic spine suggests close proximity between production site of an endocannabinoid, 2-arachidonoyl-glycerol, and presynaptic cannabinoid CB1 receptor. J Neurosci 26:4740-4751. CrossRef Medline

Zheng J, Lu Y, Perl ER (2010) Inhibitory neurones of the spinal substantia gelatinosa mediate interaction of signals from primary afferents. J Physiol 588:2065-2075. CrossRef Medline

Zylka MJ, Rice FL, Anderson DJ (2005) Topographically distinct epidermal nociceptive circuits revealed by axonal tracers targeted to Mrgprd. Neuron 45:17-25. CrossRef Medline 